\title{
The role of bacterial hypermutation in biofilm formation and antibiotic resistance in urinary tract infections caused by pathogens of the Enterobacteriaceae family
}

\section{PhD Thesis}

\author{
Béla Kovács MD \\ Supervisor: Prof. Péter Tenke MD, PhD \\ Department of Urology, Jahn Ferenc Hospital, Budapest, Hungary
}

Equipe Microbiologie, UEB, Université de Rennes 1, Rennes, France Bacteriology 1 Department, CHU Pontchaillou, Teaching Hospital, Rennes, France

Szeged

2014 


\section{List of publications concerning the subject}

I. Kovacs B, Le Gall-David S, Vincent P, Le Bars H, Buffet-Bataillon S, Bonnaure-Mallet M, Jolivet-Gougeon A.

Is biofilm formation related to the hypermutator phenotype in clinical Enterobacteriaceae isolates?

FEMS MICROBIOLOGY LETTERS 347:(2) pp. 116-122. (2013) IF: 2.049

II. Jolivet-Gougeon $A^{¥}$, Kovacs $B^{¥}$, Le Gall-David S, Le Bars H, Bousarghin L, BonnaureMallet M, Lobel B, Guille F, Soussy CJ, Tenke P.

Bacterial hypermutation: clinical implications.

JOURNAL OF MEDICAL MICROBIOLOGY 60:(5) pp. 563-573. (2011) IF: 2.502

III. Tenke P, Kovacs B, Bjerklund Johansen T E, Matsumoto T, Tambyah P A, Naber K G.

European and Asian guidelines on management and prevention of catheter-associated urinary tract infections

INTERNATIONAL JOURNAL OF ANTIMICROBIAL AGENTS 31:(SUPPL. 1) pp. 68-78. (2008) IF: 3.067

IV. Tenke P, Kovacs B, Jäckel M, Nagy E.

The role of biofilm infection in urology

WORLD JOURNAL OF UROLOGY 24:(1) pp. 13-20. (2006) IF: 1.890

V. Tenke P, Kovacs B, Benkő R, Ashaber D, Nagy E.

Continuous versus intermittent levofloxacin treatment in complicated urinary tract infections caused by urinary obstruction temporarily relieved by foreign body insertion

INTERNATIONAL JOURNAL OF ANTIMICROBIAL AGENTS 28:(SUPPL. 1) pp. 82-85. (2006) IF: 2.221 


\title{
List of publication related to the thesis
}

\author{
1. Tenke Péter, Kovács Béla, Köves Béla
}

Mit érdemes tudni a prostatitis szindróma diagnosztikájáról és kezeléséről a háziorvosi gyakorlatban?

MAGYAR CSALÁDORVOSOK LAPJA x:(2) pp. 23-27. (2009)

\section{Tenke P, Kovács B}

Nem komplikált húgyúti fertőzések kezelésének alapjai a bizonyítékok tükrében az Európai Urológusok Társasága (EAU) irányelve alapján: Szerkesztőségi irányelv

Háziorvosi Útmutató - klinikai irányelvek kézikönyve 2008/1

Budakeszi: Medition Kiadó, 2008. pp. 1-24.

3. Tenke P, Ludwig E, Köves B, Bálint P, Kovács B, Hagymási N Az urológiai beavatkozások során alkalmazott perioperatív antibakteriális profilaxis részletes irányelve (Az Európai Urológus Társaság [EAU] irányelve alapján) INFEKTOLÓGIA ÉS KLINIKAI MIKROBIOLÓGIA 15:(1) pp. 24-30. (2008)

4. Bálint P, Hagymási N, Kovács B, Köves B, Ludwig E, Magyar Infektológiai Szakmai Kollégium, Magyar Urológiai Szakmai Kollégium, Tenke P Az urológiai beavatkozások során alkalmazott perioperatív antibakteriális profilaxis részletes irányelve az Európai Urológus Társaság [EAU] irányelve alapján

MAGYAR UROLÓGIA 20:(1) pp. 30-40. (2008)

5. Tenke P, Kovács B, Bálint P, Hagymási N, Köves B

Prostatis és krónikus kismedencei fájdalom szindróma - Diagnosztika és kezelés a bizonyítékok alapján

MAGYAR UROLÓGIA 19:(3) pp. 167-180. (2007) 
6. Tenke P, Kovács B, Bálint P, Hagymási N, Köves B

Prostatis és krónikus kismedencei fájdalom szindróma: Diagnosztika és kezelés a bizonyítékok alapján

Urológiai Útmutató 2007: Klinikai irányelvek kézikönyve

Budakeszi: Medition Kiadó, 2007. pp. 99-110.

\section{Tenke P, Kovács B}

Nem komplikált húgyúti fertőzések kezelésének alapjai a bizonyítékok tükrében az Európai Urológusok Társasága (EAU) irányelve alapján: Szerkesztőségi irányelv

Útmutató - klinikai irányelvek összefoglalója 2007/1

Budakeszi: Medition Kiadó, 2007. pp. 1-24.

8. Tenke P, Köves B, Bálint P, Hagymási N, Kovács B

A visszatérő női alsó húgyúti infekciók kezelési elvei: A practical guideline to treat recurrent urinary tract infections

STD ÉS GENITÁLIS INFEKTOLÓGIA 1:(1) pp. 33-40. (2007)

9. Tenke P, Kovács B, Bálint P, Hagymási N

A nem-komplikált húgyúti fertőzések diagnosztikája és kezelése a bizonyítékok tükrében, az

Európai Urológus Társaság (EAU) irányelve alapján (Szakmai irányelv): Szakmai irányelv

MAGYAR UROLÓGIA 19:(2) pp. 123-148. (2007)

\section{Tenke P, Ludwig E, Kovács B}

A nem-komplikált húgyúti fertőzések diagnosztikája és kezelése a bizonyítékok tükrében Urológiai Útmutató 2007: Klinikai irányelvek kézikönyve

Budakeszi: Medition Kiadó, 2007. pp. 111-129.

\section{Kovács B, Tenke P}

Nem komplikált húgyúti fertőzések kezelésének alapjai a bizonyítékok tükrében az Európai Urológus Társaság (EAU) irányelve alapján

HÁZIORVOS TOVÁBBKÉPZÖ SZEMLE 12:(2) pp. 113-133. (2007) 


\section{Tenke P, Kovács B}

Nem komplikált húgyúti fertőzések kezelésének alapjai a bizonyítékok tükrében az Európai

Urológusok Társasága (EAU) irányelve alapján.: Szerkesztőségi irányelv

Útmutató - klinikai irányelvek összefoglalója. 2006/3

Budakeszi: Medition Kiadó, 2006. pp. 197-220.

\section{Kovács B, Tenke P}

A húgyhólyag gyulladásának diagnosztikája és kezelésének lehetősége a bizonyítékok tükrében PRAXIS : A MINŐSÉGI GYÓGYÍTÁS ELMÉLETE ÉS GYAKORLATA 15:(7) pp. 23-37. (2006) 


\section{Table of contents}

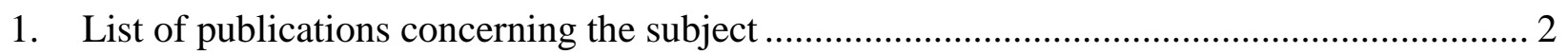

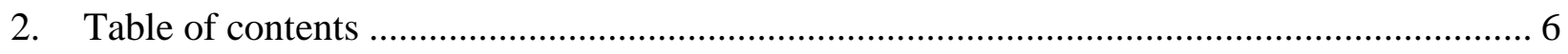

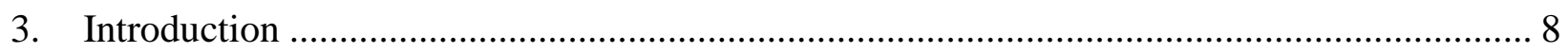

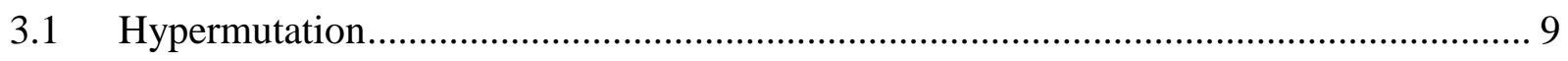

3.1.1 Molecular mechanisms of hypermutation - DNA repair ……………………........ 9

3.1.2 Molecular mechanisms of hypermutation - Recombination ................................... 11

3.1.3 Determination of mutation frequencies ……………....................................... 12

3.2 Hypermutator incidence in urinary tract infections........................................................ 13

3.3 Hypermutation and biofilm formation ……………................................................. 13

3.4 Hypermutation and antibiotic resistance ................................................................ 15

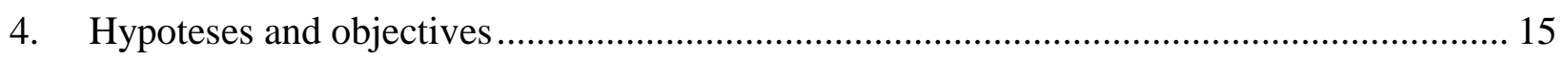

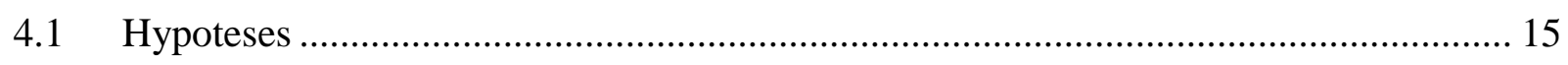

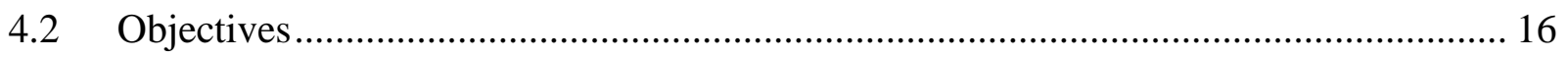

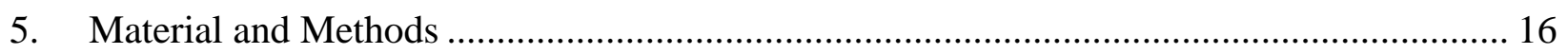

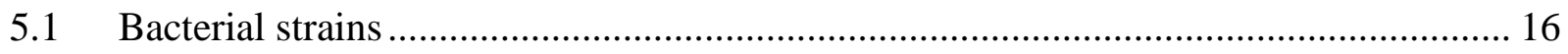

5.2 Pulse-field gel electrophoresis (PFGE) ………………………................................. 17

5.3 Determination of mutation frequencies ................................................................ 19

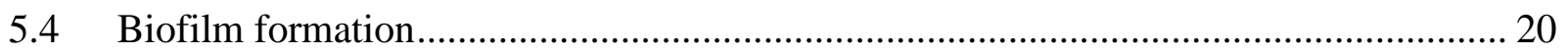

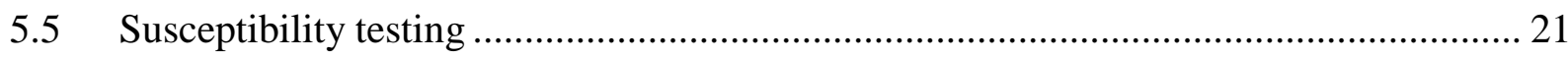

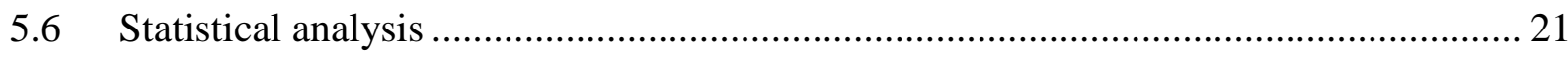

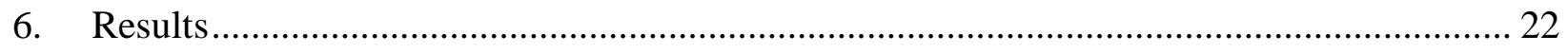

6.1 Pulse-field gel electrophoresis (PFGE) ………………........................................... 22

6.2 Mutation frequencies........................................................................................ 23 


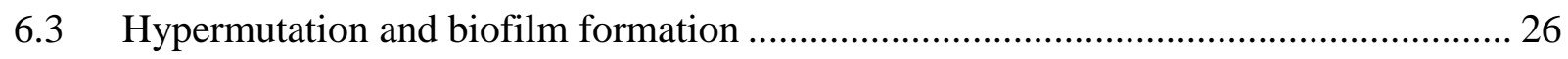

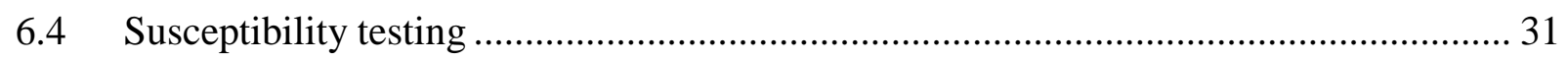

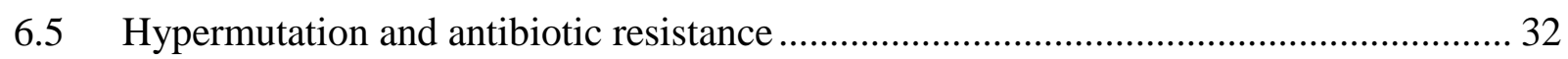

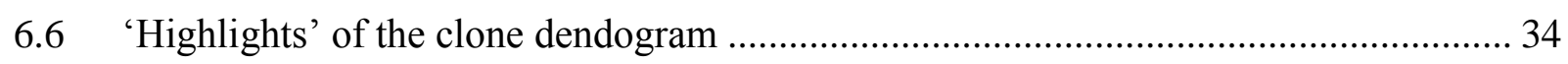

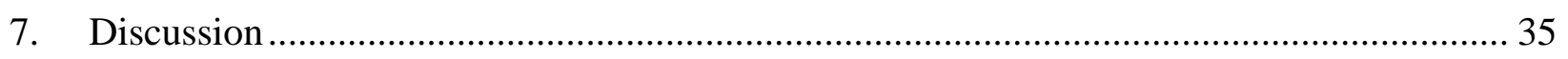

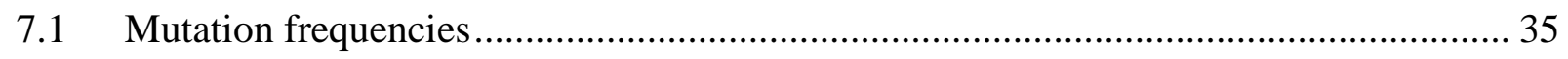

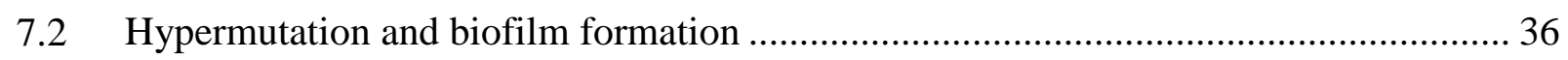

7.3 Hypermutation and antibiotic resistance …………....................................................... 38

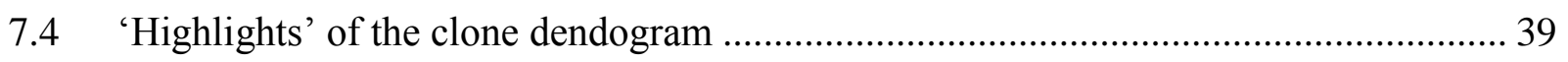

7.5 Critical remarks, limitation of this study ..................................................................... 40

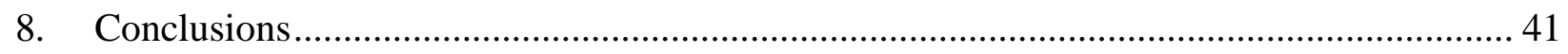

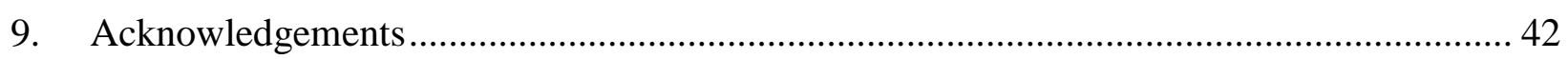

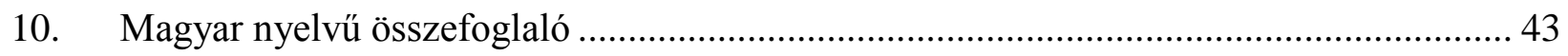

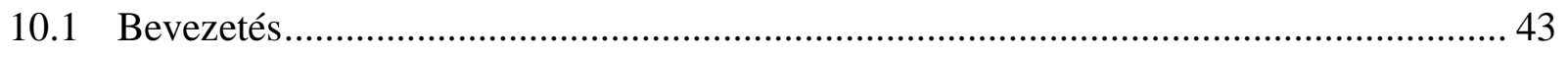

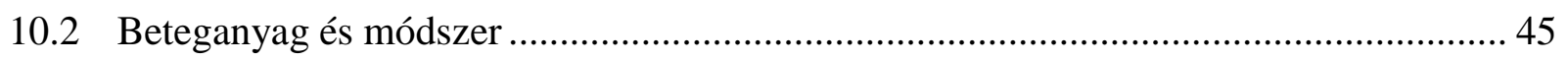

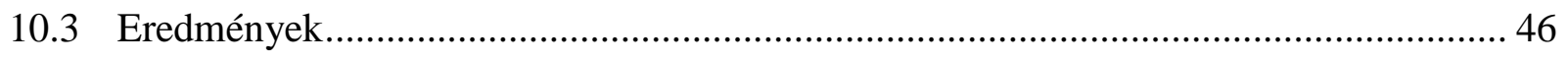

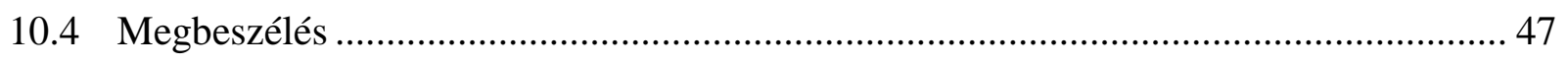

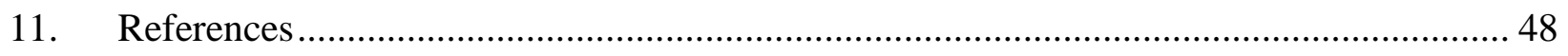




\section{Introduction}

Eradication of infectious diseases is constantly challenged by micro-organisms that develop new survival strategies. Previous studies suggest that mutational events play a predominant role in bacterial adaptation and confer a selective advantage [1,2]. Early experiments detecting mutators used mutagenized laboratory strains of bacteria, which coupled with different selection strategies. LeClerc et al reported high mutation frequency among Escherichia coli and Salmonella pathogens, challenging the theory that mutators were rare among bacterial populations [3]. These findings demonstrated that natural populations could respond to environmental selection in two ways, i.e. by enhanced mutation frequencies and by recombination.

Proteins involved in the DNA mismatch repair pathway (methyl-directed mismatch repair (MMR)) help to replace nucleotides introduced erroneously into the replicated DNA and also hinder recombination between non-identical DNA sequences. Deficiencies in any of the DNA mismatch repair pathway mechanisms can lead to a hypermutator phenotype. Transient mutator status, which involves reversion or recombination within the mutator alleles or depletion of the MMR system proteins, allows the organism to temporarily benefit from the elevated mutation frequency for adaptation while reducing the risk of accumulating deleterious mutations. Using a mathematical model, Rosche \& Foster (1999) showed that transient hypermutators play a role in adaptive mutation in E. coli [4].

The idea to investigate the association between hypermutation and biofilm forming capacity as well as antibiotic resistance in urinary tract infections (UTI) was based on several observations. The elevation of antibiotic resistance is a global problem, which affect most of the antibiotics used in UTI. E. coli hypermutators more frequently found in UTI than in other origin [5]. Both biofilm formation and acquisition of antibiotic resistance in urinary tract infections have an extensive literature. There is one clinical entity, in which significant relation between hypermutation and antibiotic resistance or between hypermutation and biofilm exists, namely cystic fibrosis (CF) lung infection. In $\mathrm{CF}$ the alveoli and bronchioli are blocked by a thick secretion, which is colonized and infected by bacteria. This mucus leads to the formation of 
bacterial microenvironments known as biofilms in the long run, which protect the pathogen against the penetration of antibiotics making infection even more difficult to eradicate.

Chronic infection, bacterial adaptation, presence of persisters and transient mutators, protection against antibiotics and antibiotic pressure are the phenomena which are both present in CF lung infection and in UTI, making these two entities similar in a certain respect. This gave me the idea to investigate hypermutation, biofilm formation and antibiotic resistance in the context of urinary tract infections.

\subsection{Hypermutation}

\subsubsection{Molecular mechanisms of hypermutation - DNA repair}

Siegel \& Bryson discovered the mutS gene in an azaserine-resistant derivative of $E$. coli had a mutator phenotype and carried a deletion in the mutS gene [6]. The majority of naturally occurring strong mutators have defects in the MMR system; the mutations are mainly in mutS [7], but deletions in genes encoding beta-clamp proteins [8] and in mutH, mutL and mutU (uvrD) have also been described (Figure 1.).

Inactivation of basal excision repair genes, e.g. mutY, mutM, mutT, can also cause a major increase in mutation rate. MutY, MutM and MutT reduce the level of 8-oxo-dG, and MutD supplies proofreading activity. In Bacillus anthracis, the mutY and mutM single knockouts are weak mutators by themselves, but the mutY mutM combination results in very high mutation rates due to G: CAT : A transversions [9]. Bacterial strains that are unable to perform any of these activities are unable to repair mismatches and, consequently, their mutation frequency increases. 


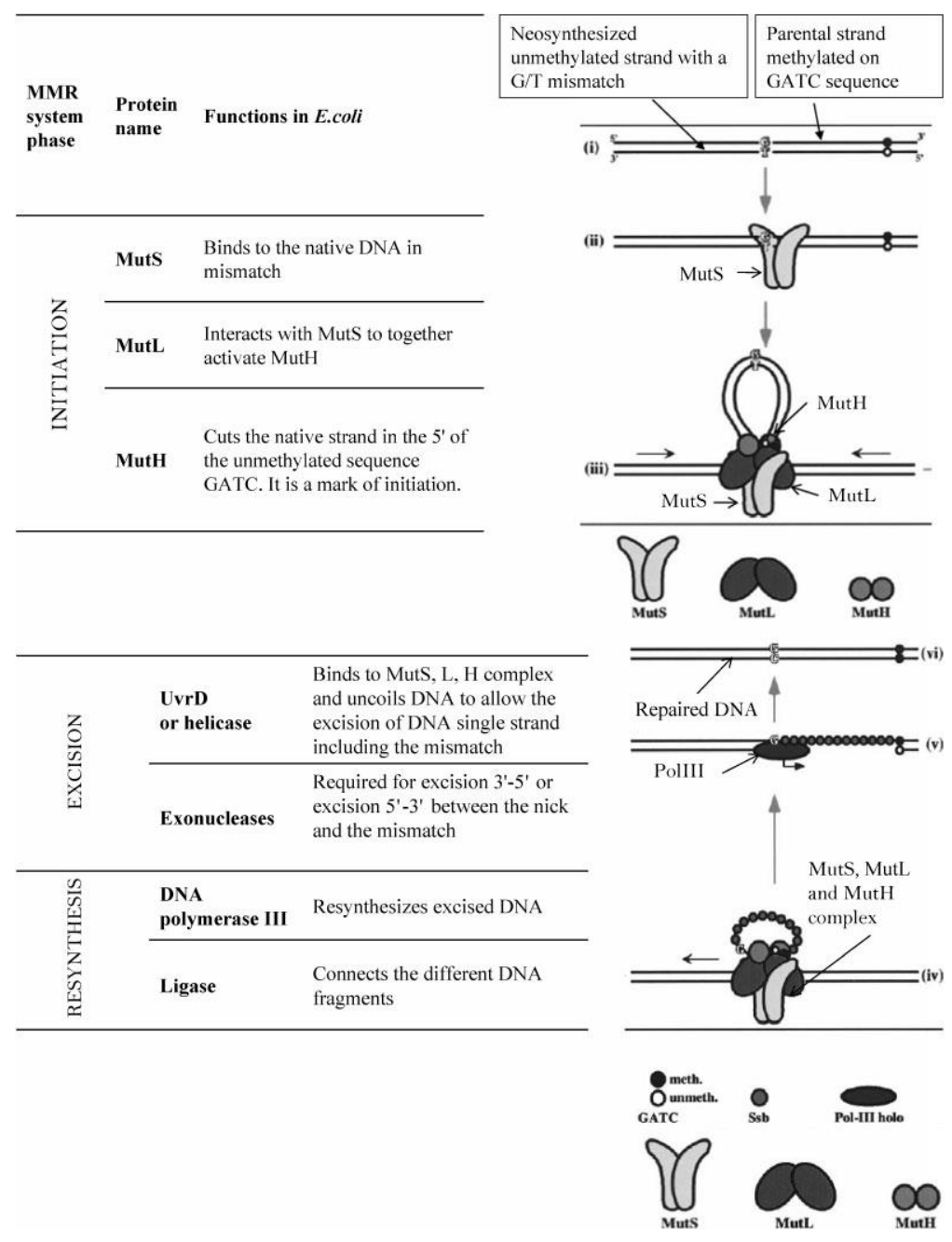

Figure. 1. MMR system DNA repair mechanism. Adapted by permission from Macmillan Publishers Ltd: EMBO J (Jiricny, 1998), copyright 1998; and by permission from Annual Reviews (Schofield \& Hsieh, 2003). The initiation of mismatch repair requires MutS, MutL and MutH; the latter generates a nick in the unmethylated strand of a nearby hemimethylated d(GATC) sequence. Both MutS and MutL are dimeric ATPases: MutS recognizes and binds the mismatch and recruits MutL, which binds the MutS- mismatch complex. The endonuclease MutH is stimulated to catalyze endonucleolytic cleavage at the unmethylated d(GATC) site in the presence of MutL and MutS. DNA unwinding is then initiated at the nick by DNA helicase II (UvrD) and the repair itself is catalyzed by the DNA polymerase III holoenzyme. 
Mismatch repair systems are highly conserved in bacterial populations and evolved from common ancestors, i.e. the Hex system in Gram-positive Streptococcus pneumoniae and the Mut system in Gram-negative E. coli and Salmonella enterica serovar Typhimurium. There is homology between HexA and MutS and between HexB and MutL in Streptococcus pneumoniae $[10,11]$ and Saccharomyces cerevisiae [12].

Disruptions of genes other than mut can also result in a hypermutator phenotype. For example, DNA adenine methylation by DNA adenine methyltransferase (Dam) plays an important role in DNA replication, gene expression regulation and DNA methylation for strand discrimination

during mismatch repair [13]. Strains deficient in Dam are hypersensitive to DNA-damaging agents or reactive oxygen species [14]. Insertional inactivation of dam and/or drg (damreplacing genes) results in hypermutator phenotypes [15].

Other mutants with inactivated DNA repair genes have also been reported. These include isolates with inactivation of the alkylation damage repair gene ada/alkA in several Mycobacterium tuberculosis isolates and in one Mycobacterium bovis strain [16] and E. coli isolates with an inactivated dnaQ gene, which encodes the epsilon subunit of DNA polymerase III [17].

Recently, Rodríguez-Rojas \& Blázquez looked for additional genes involved in hypermutability by screening a Pseudomonas aeruginosa library with random insertions. Mutational inactivation of pfpI, which putatively encodes a member of the DJ-1/ThiJ/PfpI superfamily, was found to confer a hypermutator phenotype [18].

\subsubsection{Molecular mechanisms of hypermutation - Recombination}

Recombination requires the genetic recombination genes $\operatorname{rec} \mathrm{B}, \operatorname{recC}$, recD and $\operatorname{rec} \mathrm{A}$, which are part of the bacterial RecBCD recombination system. These proteins generally require nearperfect homology between the two complementary DNA strands, but this requirement is greatly relaxed in MMR-deficient mutants. Recombination-deficient recA and recB null mutant strains are deficient in adaptive reversion. A hyper-recombinogenic recD strain is hypermutable, and its hypermutation depends on functional recA and recB genes (Harris et al., 1994) [19]. Worth et al. 
(1994) showed that MutS abolishes recA catalyzed strand transfer between the DNA of the fd and M13 bacteriophages, which vary by 3\% at the nucleotide level, but has no effect on M13M13 or fd-fd exchange [20]. Although MutL has no effect on M13-fd heteroduplex formation, the protein dramatically enhances inhibition of MutS-mediated strand transfer. Analysis of strand-transfer intermediates that accumulate in the presence of MutS and MutL indicates that the proteins block branch migration, presumably in response to mispairs within the newly formed heteroduplex. Transduction between Salmonella typhimurium and Salmonella typhi is blocked by the activity of the recipient's mismatch repair system, which senses sequence divergence and disrupts heteroduplexes in favor of recipient sequences [21].

\subsubsection{Determination of mutation frequencies}

All the mutations present in a given population at a chosen time can be measured by determining the mutation frequency in distinction to the "mutation rate", which is frequently used in the same manner, but refers to the rate of mutation within the genome per generation [22]. Usually the mutation frequency of a bacterial population is of the order of $10^{6}$ to $10^{7}$, but numerous studies have described organisms which exhibit permanent mutation frequencies 10-1000-fold or even higher than the median value of their bacterial population, including clinical pathogens and animal sources [5] [23] [24]. These clones are termed as hypermutators. In order to better define the medium value of mutation frequencies for bacteria with a hypermutator phenotype, polymorphisms in rifampicin resistance genes have been studied by Baquero et al, who defined 4 categories of $E$. coli strains according to their findings on mutation frequencies (f), and named them as hypomutable $\left(f \leq 8 \times 10^{-9}\right)$, normomutable $\left(8 \times 10^{-9}<f<4 \times 10^{-8}\right)$, weak mutator $\left(4 \times 10^{-8} \leq f\right.$ $\left.<4 \times 10^{-7}\right)$, and strong mutator $\left(f \geq\right.$ to $\left.4 \times 10^{-7}\right)$ [25]. Denamur et al proposed that a strain should be considered a mutator strain when the frequencies of mutations that conferred resistance to rifampicin were 10-fold higher than the median value of mutagenesis observed for all the studied strains (these were termed ' 10 -fold mutators'). Strains that displayed a $>50$-fold increase in mutagenesis were considered strong mutators (50-fold mutators) [5]. E. coli is far the most frequent pathogen in UTI, followed by other species of the Enterobacteriaceae family. The 
former is investigated in detail, but data about the mutation frequency of the latter group was missing in the literature.

\subsection{Hypermutator incidence in urinary tract infections}

Hypermutators make up about $0.1 \%$ of the natural E. coli population [3], but this incidence is sometimes higher in clinical strains [5, 25]. Denamur et al studied a population of 603 E. coli strains, some commensal (i.e. fecal samples collected from healthy unrelated human subjects) and some pathogenic (from patients with bacteraemia, from patients with UTIs, enteroinvasive or enterohaemorrhagic pathogens, or from newborn meningitis) [5]. They found no significant difference in the frequency of mutators between the two groups. However, mutator strains occurred significantly more frequently among UTI strains. These results were confirmed by Baquero, who found a higher frequency of weak mutators in urinary tract isolates $(25 \%)$ and in blood isolates (38 \%). Studying 696 E. coli strains from patients with UTIs in Sweden, Denmark and Spain he found that $23 \%$ were weak mutator and $0.7 \%$ was strong mutator [25]. The proportion of weak mutators among the Danish isolates was significantly lower than in the Spanish blood isolates, indicating geographical differences in the mutation frequency distribution profiles.

\subsection{Hypermutation and biofilm formation}

The initial goal of this thesis was to show a possible relationship between hypermutation and antibiotic resistance in UTI. After the first results I started to collect the literature when I realized some possible similarity between the microenvironment of CF lung infection and of urological biofilms. It is now evident, that $P$. aeruginosa isolated from respiratory samples in patients with cystic fibrosis showed a higher proportion of hypermutable strains in biofilms. So we decided to do a pilot study about the biofilm formation feature of the samples which we could compare with 
the hypermutation and resistance feature. Since we observed some promising data, we have done an adhesion test as the initial step of biofilm formation for the whole series.

The ability of microorganisms to adhere to surfaces is influenced by electrostatic and hydrophobic interactions, ionic strength, osmolality and urinary $\mathrm{pH}[26,27]$. Several theories have been put forth to explain the complex interaction that occurs as a microbe approaches and then attaches to a surface. However, the precise mechanisms of attachment to biomaterials are still under investigation.

In order to react to a surface or an interface like an air-water interface, bacteria must be able to 'sense' their proximity to these surfaces. The planktonic 'free-floating' bacterial cells release both protons and signaling molecules as they move through the bulk fluid. These protons and signaling molecules must diffuse radially away from the floating cell, if not adjacent to any surface or interface. But a significantly higher concentration of either protons or signaling molecules can develop on the side of the bacterial cell close to any surface. This allows the cell to sense that it is near to a surface because diffusion is limited on this side [28]. After the planktonic bacterial cell has sensed the surface, it may commit to the active process of adhesion and biofilm formation.

There is no single process or theory, which can completely describe microbial adhesion. The initial adhesion is reversible and involves hydrophobic and electrostatic forces. It is followed by irreversible attachment provided by bacterial polysaccharides which anchor the organisms to the surface. Subsequently, colonization takes place in accordance with species' factors, such as slow migration and spreading, rolling, packing and adhesion. A developed biofilm consists of groups of microorganisms, sometimes in mushroom-like forms, separated by interstitial spaces that are filled with the surrounding fluid [29]. The growth rates of organisms on a surface as well as the strategies used by microorganisms to spread over a surface are important for colonization. These strategies are species specific and can influence the distribution of a biofilm on a surface [30].

Mutator phenotypes in P. aeruginosa can enhance microcolony initiation and growth during biofilm formation. It is showed that bacteria within microcolonies exhibit enhanced mutation frequencies and vice versa, bacteria with an elevated mutation frequency can exhibit enhanced 
microcolony development. Microcolonies are foci of cell division and growth within biofilms [31], which may explain why mutations are localized within microcolonies of biofilms.

\subsection{Hypermutation and antibiotic resistance}

The increasing resistance of the most common uropathogens against the majority of antibiotics used in UTI is a global problem. The mechanism of Enterobacteriaceae acquiring resistance has been widely studied and many of the modalities have been described. If mutators have a role in the emergence of antibiotic resistance under natural conditions, such strains are expected to occur in natural populations, including clinical specimens [8]. Although the relationship between hypermutability and the acquisition of antibiotic resistance has been extensively investigated, the evidence of the association among different species remains conflicting except for cystic fibrosis $[25,32]$. From the available data, it is still not clear whether high mutation frequencies are particularly important for the global evolution of pathogen populations, including antibiotic resistance acquisition [3, 33-35].

\section{Hypoteses and objectives}

\subsection{Hypoteses}

(1) Clones of the most common uropathogens belong to the Enterobacteriaceae family with hypermutable phenotype are more likely to be resistant to antibiotics.

(2) The higher the mutation frequency of the studied population the greater the ability to initiate biofilm formation. 


\subsection{Objectives}

(1) To show the frequency of mutation for the first time in a highly diverse collection of Enterobacteriaceae strains collected from urine of UTI patients and from blood stream isolates.

(2) To investigate the capacity of strains to initiate biofilm formation.

(3) To explore the relationship between mutation frequency and biofilm formation.

(4) To determine the antibiotic resistance of the isolates against the most common antibiotics used in UTI.

(5) To show a possible link between hypermutable strains and acquisition of antibiotic resistance.

\section{Material and Methods}

\subsection{Bacterial strains}

A total of 4000 clinical strains were screened for Enterobacteriaceae species admitted to the Urologic and Nephrologic Department of Pontchaillou University Hospital, in Rennes, France from January to December 2007. Samples with polymicrobial results were excluded.

The next step was the duplication of each strain in order to get the collection for the research. Agar medium was used to check the purity of the strain, than they were conserved on $-80^{\circ} \mathrm{C}$. The special deep-frozen medium contains pearls (15-20 pieces) (Cryobank TM Mixed (4x16), Mast Group Ltd, Bootle, Merseyside UK), each of which is sufficient for reproducing the baseline strain and gave the opportunity to repeat the dilution procedure three times or to repeat any case of questioned result. For the security of conserving the strains for one year and avoiding an unexpected event, deep-frozen samples was made in duplicate and held separately. 
The blood samples were selected and studied by the institute followed the protocol I used for the UTI samples and the results were provided for further analysis.

\subsection{Pulse-field gel electrophoresis (PFGE)}

Preparation of the cellular DNA for PFGE followed the protocol of Allardet-Servent et al with minor modifications [36]. DNA contained in agarose plugs was restricted for $4 \mathrm{~h}$ with SfiI endonuclease (20 U) (New England BioLabs ${ }^{\circledR}$ Inc.) for Proteus mirabilis strains and with XbaI (40 U) (New England BioLabs ${ }^{\circledR}$ Inc.) for all other species. Electrophoresis was performed at 6 $\mathrm{V} / \mathrm{cm}$ with a field angle of $120^{\circ}$ for 22 hours with a switch time of 5 to $35 \mathrm{~s}$ at $14{ }^{\circ} \mathrm{C}$ and 24 hours at 30 to $70 \mathrm{~s}$ at $14{ }^{\circ} \mathrm{C}$ for $P$. mirabilis using a contour-clamped homogeneous electric field DR III apparatus (CHEF-DR III, BioRad, Ivry-sur-Seine, France). Bacteriophage lambda DNA ladders (Sigma) were included as size standards. Gels were then stained using SYBR ${ }^{\circledR}$ Green I (Lonza Inc.) and photographed under ultraviolet light (Picture 1.). PFGE patterns were compared by calculating the Dice correlation coefficient with the Gel Compar II software (Applied Maths, St-Martens-Latem, Belgium) and were clustered into a dendrogram using the unweighted pair group matching method (tolerance, 2.0\%) (Figure 1.). Two isolates were considered genetically related if their Dice coefficient was $85 \%$ or higher. Solely the unique patterns were considered for the statistical analysis. 


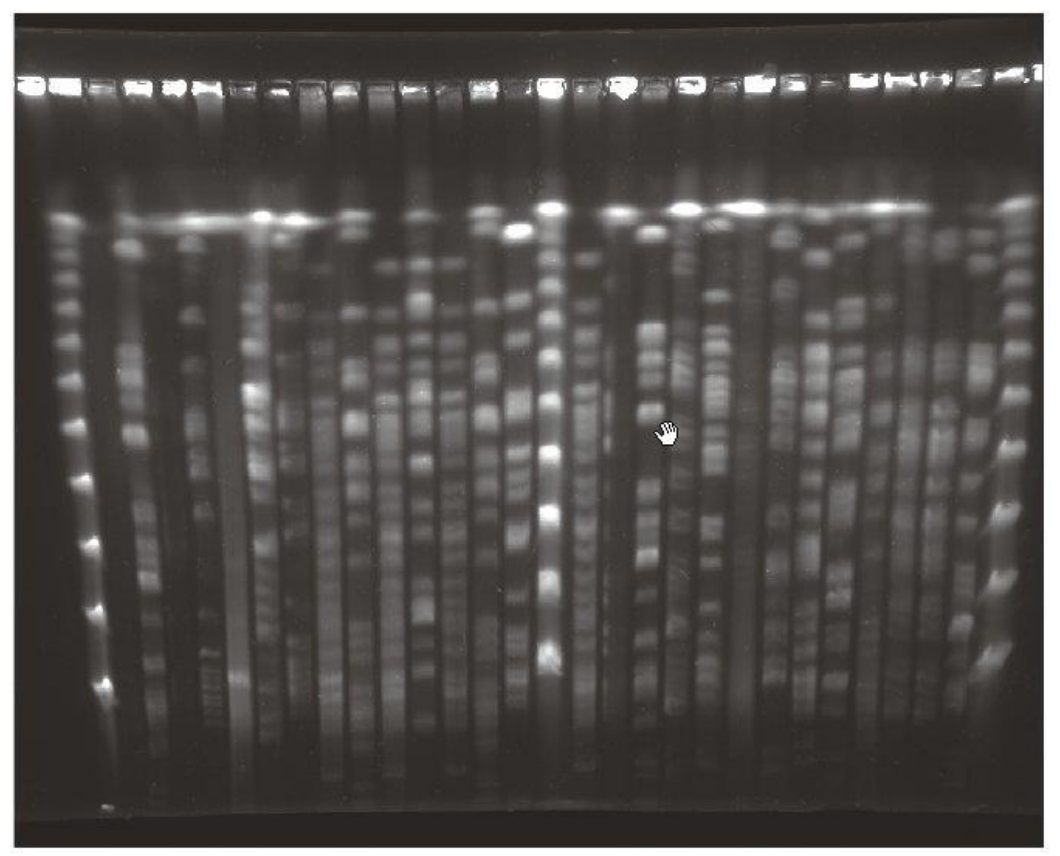

Picture 1. Photograph of DNA particles under ultraviolet light after PFGE.

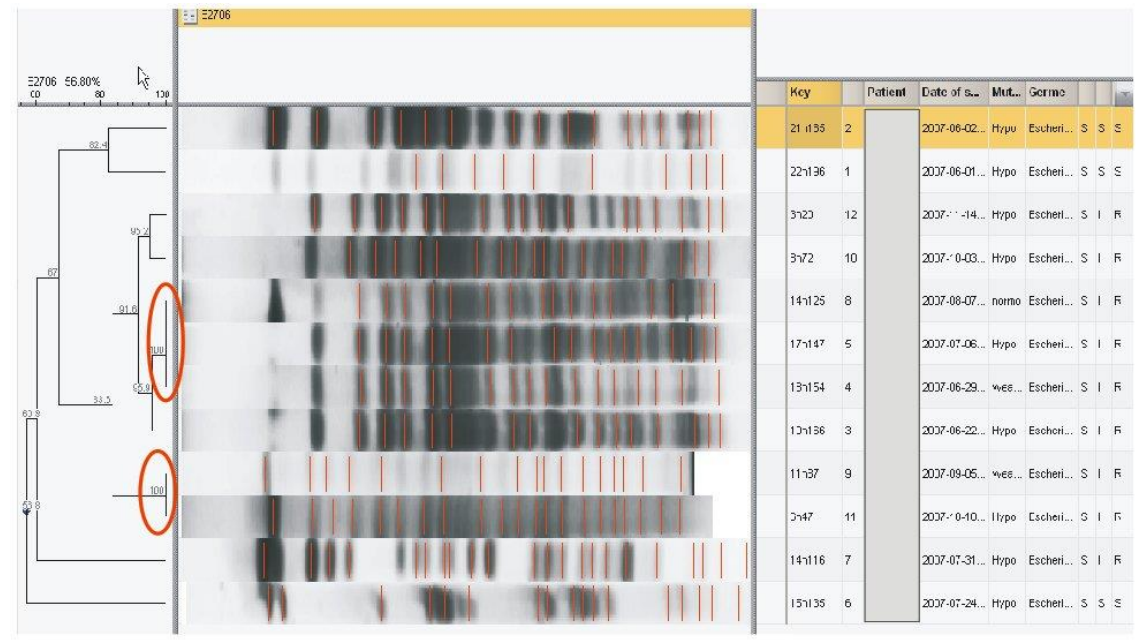

Figure 1. Comparison of PFGE patterns by dendograms. Photograph made by the Gel Compar II software (Applied Maths, St-Martens-Latem, Belgium). 


\subsection{Determination of mutation frequencies}

Bacteria from the strain collection were spread onto agar plate (soy tryptase, TS) 18 hours (h), at $37^{\circ} \mathrm{C}$ to verify the purity of the strain. One isolated colony is incubated in $10 \mathrm{ml}$ Luria Bertani (LB) broth for $18 \mathrm{~h}$, at $37^{\circ} \mathrm{C}$, continuously stirred at $150 \mathrm{rpm}$. Serial dilutions of the preculture made in sterile distilled water $(10 \mathrm{ml}) 10^{-1} 10^{-2} 10^{-3} 10^{-4} 10^{-5} 10^{-6} 10^{-7}$ and $10^{-8}$ respectively. Then $100 \mu \mathrm{L}$ of dilutions $10^{0}$ and $10^{-1}$ are spread onto agar LB + rifampicin, and $10^{-6}, 10^{-7}$ and $10^{-8}$ onto agar LB without rifampicin (Figure 2.).

The mutation frequency corresponds to the number of bacteria resistant to rifampicin / the total number of bacteria:

$$
=\frac{\frac{N \times 10^{-1}+N \times 10^{-2}}{2}}{\frac{N \times 10^{-7}+N \times 10^{-8}}{2}}
$$

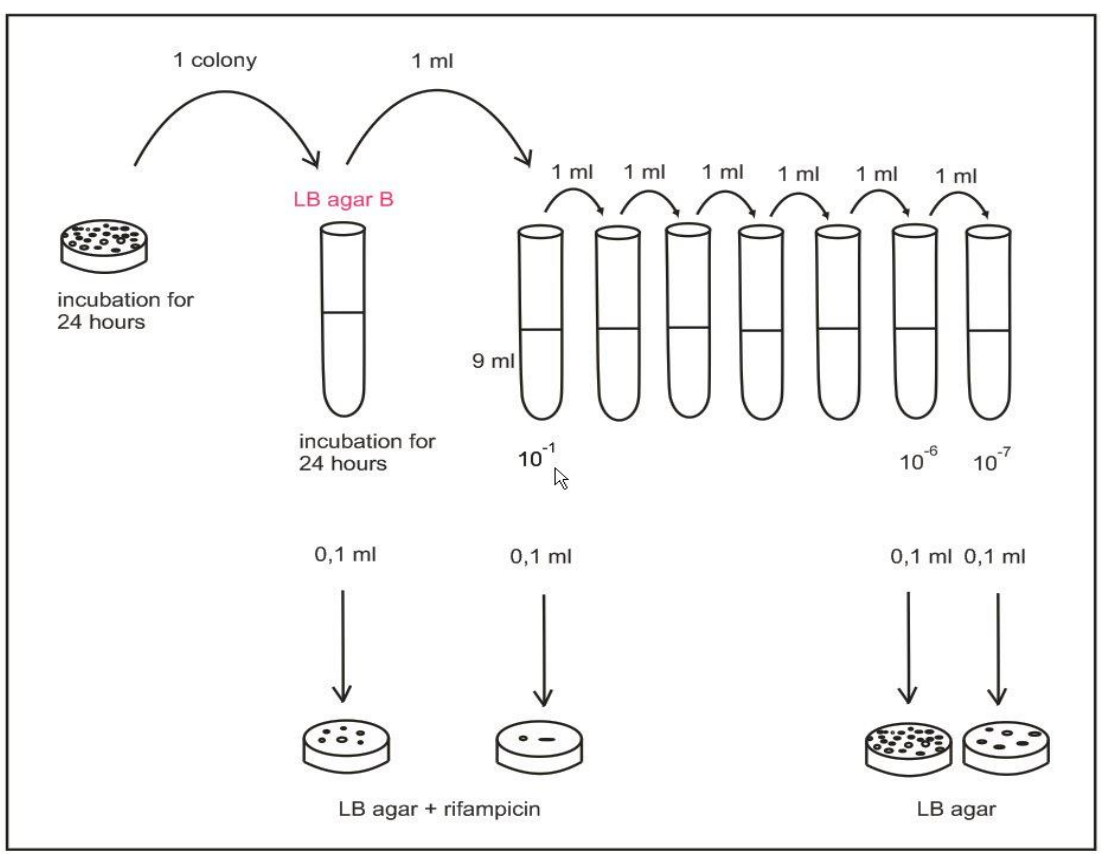

Figure 2. Serial dilution method for mutation frequency counting. 
The number of colonies was counted and mutation frequencies were estimated. We used two methods for the evaluation of mutation frequencies. We considered the categorization described by Baquero, where a strain determined as normomutable when the mutation frequency (f) was equal or close to the modal point of the distribution of mutation frequencies. The results for the different species were categorized as previously described for E. coli strains. If the value is less than or equal to $(N \leq) 8 \times 10^{-9}$, it means that the bacterium is hypomutable, if the value is $8 \times 10^{-9}<$ $N<4 \times 10^{-8}$, it means that the bacterium is normomutable, when it is $4 \times 10^{-8} \leq N<4 \times 10^{-7}$, it is a week mutator, and finally, if it is $N \geq$ to $4 \times 10^{-7}$, it means that the strain is a strong mutator [25]. According to Denamur et al, strains displaying a > 50-fold increase of the median value of mutagenesis were considered strong mutators and a 10- to 50-fold increase as weak mutators [5].

The experiment was repeated in triplicate. The results were related to the mean value obtained from three independent cultures of about $10^{8} \mathrm{CFU} / \mathrm{mL}$. When mutation frequencies were $\geq 4 \mathrm{x}$ $10^{-8}$, mutation frequencies were also tested with lower (about $10^{7} \mathrm{CFU} / \mathrm{mL}$ ) or higher (about $10^{9}$ $\mathrm{CFU} / \mathrm{mL}$ ) inocula and, if necessary, with another antibiotic (fosfomycin $30 \mu \mathrm{g} / \mathrm{mL}$ ), to eliminate the possibility of 'jack-pot' emergence that might disturb the calculation of mutation frequencies.

\subsection{Biofilm formation}

The initiation of biofilm formation was assayed using polystyrene microtiter plates, as described previously, with some modifications [37]. Specifically, one fresh colony of each strain was inoculated into $10 \mathrm{~mL}$ tryptic soy (TS) broth and cultured for $2 \mathrm{~h}$. Samples $(150 \mu \mathrm{L})$ of exponential-growth-phase bacteria were removed and incubated overnight $(18 \mathrm{~h})$ at $37^{\circ} \mathrm{C}$ in 96 well microtiter polystyrene plates (Falcon MicrotestTM 96; Becton Dickinson, Meylan, France). After removal of the medium, crystal violet $(0.4 \%$ solution; $150 \mu \mathrm{L})$ was added to the emptied wells to stain the biofilm if present. The biofilm was quantified at least in triplicate for each sample. Streptococcus gordonii (strain Challis/ATCC 35105/CH1/DL1/V288) and bovine Salmonella Heidelberg B182 [24] were used as positive controls. Escherichia coli HB 101 and sterile TS culture broth were used as negative controls. The mean OD570 nm value (ODm) was calculated for three wells. A cut-off value (ODc) was established as three standard deviations 
above the mean OD570 $\mathrm{nm}$ of the three negative controls in each plate. Biofilm production was calculated as the ODm/ODc ratio as recommended by Stepanovic et al [37]. The studied strains were classified into four categories: no biofilm producer $($ ratio $\leq 1),+$ biofilm producer $(1<$ ratio $\leq 2),++$ biofilm producer $(2<$ ratio $\leq 4)$ and +++ biofilm producer (ratio $>4)$. The raw value of the ratio was used for the correlation calculations.

\subsection{Susceptibility testing}

Susceptibilities of commonly used antibiotics for treatment of urinary tract infections or surgical prophylaxis (nalidixic acid, ciprofloxacin, norfloxacin, cefalotin, cefoxitin, ceftazidime, cefotaxime, fosfomycin, gentamicin, amoxicillin, amoxicillin+clavulanic acid and cotrimoxazole) were determined at admission, using agar diffusion and E tests methods, according to the current CASFM (Comité de l'Antibiogramme de la Société Française de Microbiologie (2007) and CLSI (Clinical and Laboratory Standards Institute, formerly NCCLS) guidelines 2007. AmpC overproducers were detected by their characteristic antibiotype, namely resistance to all beta-lactams except carbapenems and cefepime with no influence of clavulanic acid on MIC values of cefotaxime and cefepime. Production of extended spectrum betalactamases (ESBL) was detected using double-disk synergy assay and E-tests (ESBL E-test, AB Biodisk).

\subsection{Statistical analysis}

Continuous data were expressed as mean values \pm standard deviation or as median and percentile 25 and 75, and discrete data as percentages. Comparisons between two groups were performed by two-sided Fisher's exact test for count data or the Mantel-Haenszel chi-square test for stratified data or Student's $t$ and chi-square tests, $P$ value of $<0.05$ was considered as statistically significant. For the purpose of analysis, "non-susceptible" count included both the intermediate 
and resistant categories. Statistical analyses were performed with the SPSS software (SPSS Inc., Chicago, Illinois, USA).

\section{Results}

\subsection{Pulse-field gel electrophoresis (PFGE)}

Three-hundred sixty-nine clinical strains of Enterobacteriaceae were selected from urine samples of 218 patients for further analysis after purity examination and the exclusion of polymicrobial samples. The evaluation of PFGE determined 222 unique clones (isolated from 195 patients). Four, 3 and 2 different clones were isolated from the same patient in 1, 7 and 18 cases, respectively. Two patients harbored a strain with identical PFGE pattern, mutation categories and susceptibility values to another patient's. One of each of these duplicated clones was excluded from the analysis. There were 15 patients who had more than one identical clone from which we used the first one. The remaining 222 different Enterobacteriaceae strains from urine samples together with the 213 blood isolates were distributed as indicated in table 1:

\begin{tabular}{lcc}
\hline \multicolumn{1}{c}{ Species } & $\begin{array}{c}\text { № of isolates with unique PFGE pattern } \\
\text { Urine }\end{array}$ & Blood \\
\hline E. coli & 161 & 149 \\
K. oxytoca & 7 & 11 \\
K. pneumonia & 15 & 13 \\
C. koseri & 2 & 4 \\
C. freundii & 11 & - \\
P. mirabilis & 10 & 8 \\
M. morganii & 5 & 3 \\
S. marcescens & 7 & 6 \\
P. rettgeri & 4 & - \\
H. alvei & - & 2 \\
E. aerogenes & - & 2 \\
S. enterica Typhi & - & 1 \\
E. cloacae & - & 14 \\
$\quad$ Total & $\mathbf{2 2 2}$ & $\mathbf{2 1 3}$ \\
\hline
\end{tabular}




\subsection{Mutation frequencies}

The mutation frequency distribution was calculated for the whole collection. According to Baquero's criteria, $10.3 \%$ hypomutable $\left(\mathrm{f} \leq 8 \times 10^{-9}\right), 64.8 \%$ normomutable $\left(8 \times 10^{-9}<\mathrm{f}<4 \times 10^{-8}\right)$, $23 \%$ weak mutator $\left(4 \times 10^{-8}<\mathrm{f}<4 \times 10^{-7}\right)$, and $1.8 \%$ strong mutator ( $\geq 4 \times 10^{-7}$ ) strains was revealed. One-hundred weak mutators (57 UTI and 43 BSI strains) and 8 strong mutators were isolated [five UTI strains (one C. freundii and four E. coli) and 3 BSI strains (two E. cloacae and one E. coli)] (Table 2.). The distribution pattern of mutation frequencies for the Enterobacteriaceae collection without the E. coli strains showed close similarity to the distribution of the E. coli strains (Figure 3.). In this collection of Enterobacteriaceae, a submajority population whose mutation frequency was $1 \times 10^{-8}\left(1 \times 10^{-8} \leq \mathrm{f}<2 \times 10^{-8}\right)$, and a smaller subpopulation with a mutation frequency 10 -fold higher $\left(1 \times 10^{-7} \leq \mathrm{f}<2 \times 10^{-8}\right)$ was already described as normomutators and weak mutators [25]. Between these two populations, strains have intermediate rates, mainly between $3 \times 10^{-8}$ and $1 \times 10^{-7}$. To confirm the distinct modal mutation frequencies and the threshold proposed by Baquero et al, the analysis has been repeated and limited to strains with the characteristic rate of $1 \times 10^{-8}$ and $1 \times 10^{-7}$, respectively, considered as normomutators and weak mutators. In this specific population, 115 strains were normomutators (including 84 E. coli and 31 other Enterobacteriaceae; 63 from BSI and 52 from UTI) with a mutation frequency between $1 \times 10^{-8}$ and $1.98 \times 10^{-8}$. We also found 27 weak mutators (including 19 E. coli and 8 other Enterobacteriaceae: 8 from blood cultures and 19 from urine) with a mutation frequency between $1 \times 10^{-7}$ and $1.91 \times 10^{-7}$. Mutation frequency calculations using the criteria defined by Denamur et al helped to highlight 10-fold and 50-fold mutator E. coli strains: for the whole collection, $4.1 \%$ of the UTI and $1.9 \%$ of BSI isolates were 10-fold mutators, while $0.9 \%$ of the UTI and none of the BSI isolates were 50-fold mutators [5]. 


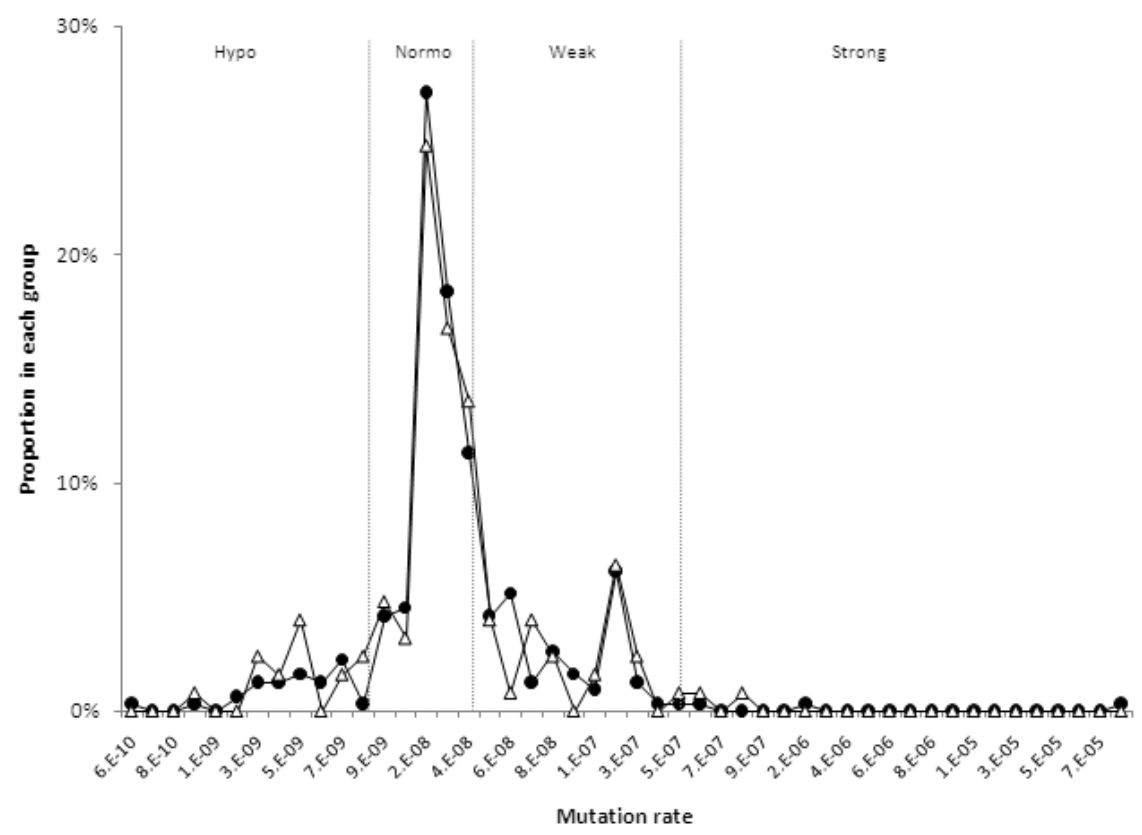

Figure 3. Distribution of the mutation frequencies to rifampicin resistance for 310 Escherichia coli (black circles) and 125 other Enterobacteriaceae (white triangles) clinical strains. The vertical lines indicate the thresholds proposed for E. coli by Baquero et al. (2004). The mutation frequencies of E. coli and other Enterobacteriaceae species showed the same distribution, which was similar to that presented in the paper by Baquero et al. (2004). 


\begin{tabular}{|c|c|c|}
\hline $\begin{array}{l}\text { Mutation frequency }(f) \\
\text { status* }\end{array}$ & $\begin{array}{l}\text { Enterobacteriaceae } \\
\text { species }\end{array}$ & $\begin{array}{l}\text { Total } \\
\text { (No of isolates) }\end{array}$ \\
\hline Hypomutable & E. coli & 29 \\
\hline \multirow{8}{*}{$\mathrm{f} \leq 8 \times 10^{-9}$} & K. oxytoca & 7 \\
\hline & K. pneumoniae & 2 \\
\hline & C. koseri & 2 \\
\hline & S. marcescens & 2 \\
\hline & C. freundii & 1 \\
\hline & M. morganii & 1 \\
\hline & P. mirabilis & 1 \\
\hline & Total Hypo & 45 \\
\hline Normomutable strains & E. coli & 203 \\
\hline \multirow{13}{*}{$8 \times 10^{-9}<\mathrm{f}<4 \times 10^{-8}$} & K. pneumoniae & 20 \\
\hline & P. mirabilis & 10 \\
\hline & E. cloacae & 9 \\
\hline & K. oxytoca & 9 \\
\hline & S. marcescens & 9 \\
\hline & M. morganii & 6 \\
\hline & C. freundii & 5 \\
\hline & P. rettgeri & 4 \\
\hline & C. koseri & 3 \\
\hline & H. alvei & 2 \\
\hline & E. aerogenes & 1 \\
\hline & S. enterica Typhi & 1 \\
\hline & Total Normo & 282 \\
\hline \multirow[t]{2}{*}{ Weak mutator strains } & E. coli & 73 \\
\hline & P. mirabilis & 7 \\
\hline \multirow[t]{9}{*}{$4 \times 10^{-8}<\mathrm{f}<4 \times 10^{-7}$} & K. pneumoniae & 6 \\
\hline & C. freundii & 4 \\
\hline & E. cloacae & 3 \\
\hline & K. oxytoca & 2 \\
\hline & S. marcescens & 2 \\
\hline & C. koseri & 1 \\
\hline & E. aerogenes & 1 \\
\hline & M. morganii & 1 \\
\hline & Total Weak & 100 \\
\hline Strong mutator strains & E. coli & 5 \\
\hline \multirow{3}{*}{$\mathrm{f} \geq$ to $4 \times 10^{-7}$} & E. cloacae & 2 \\
\hline & C. freundii & 1 \\
\hline & Total Strong & 8 \\
\hline Total & & 435 \\
\hline
\end{tabular}

Table 2. Mutation frequency distribution according to Baquero's criteria (2004). 


\subsection{Hypermutation and biofilm formation}

Higher biofilm-forming capacity was observed in UTI strains than in BSI strains: 140/222 (63.1\%) and 90/213 (42.3\%), respectively (Table 3-4.). The results were similar for the E. coli subpopulation in UTI strains $(87 / 161 ; 54.0 \%)$ and BSI strains $(71 / 149 ; 47.7 \%)$. The MantelHaenszel chi-squared test for stratified data (with E. coli in stratum 1, and other Enterobacteriaceae in stratum 2) gave a chi-square statistic $=18.4$, a P-value $<0.001$ and an Odds ratio $=2.26 ; 95 \%$ CI $[1.55-3.28]$. As expected among the urease producer Proteus mirabilis strains, 10/10 (100\%) and 0/8 were biofilm producers in UTIs and BSIs, respectively ( $\mathrm{P}<0.001)$. Of the Klebsiella pneumoniae isolates, which are also urease positive, 14/15 (93.3\%) of UTI and 3/13 (23.1\%) of BSI isolates were biofilm producers ( $\mathrm{P}<0.001)$. No significant difference in biofilm production was demonstrated for $E$ coli UTI strains (87/161; $54.0 \%)$ vs. BSI strains $(71 / 149 ; 47.7 \%)$. Some biofilm-producing species (i.e. P. mirabilis) are particularly isolated from urine during pyelonephritis associated with bacteraemia, compared with digestive translocation or other origin. The great majority of $K$. pneumoniae UTI strains are biofilm producers; however, this is not the case for BSI strains (urinary, pulmonary or digestive origin) (Table 3A-B). In our series, only $35.2 \%$ of the BSI strains had a proven urinary tract origin. 


\begin{tabular}{|c|c|c|c|c|}
\hline Mutation frequency $(f)$ & Enterobacteriaceae & Urin: & y strains & \\
\hline status* & species & $\begin{array}{l}\text { No biofilm } \\
\text { producers** }\end{array}$ & $\begin{array}{l}\text { +Biofilm } \\
\text { producers }\end{array}$ & Total \\
\hline Hypomutable & E. coli & 6 & 11 & 17 \\
\hline$f<8 \times 10^{-9}$ & C. freundii & - & 1 & 1 \\
\hline $1=0 \times 10$ & Total Hypo & 6 & 12 & 18 \\
\hline Normomutable strains & E. coli & 45 & 54 & 99 \\
\hline $8 \times 10^{-9}<\mathrm{f}<4 \times 10^{-8}$ & K. pneumoniae & - & 13 & 13 \\
\hline & P. mirabilis & - & 3 & 3 \\
\hline & K. oxytoca & 1 & 5 & 6 \\
\hline & S. marcescens & 2 & 4 & 6 \\
\hline & M. morganii & 2 & 3 & 5 \\
\hline & C. freundii & 1 & 4 & 5 \\
\hline & P. rettgeri & 1 & 3 & 4 \\
\hline & C. koseri & - & 1 & 1 \\
\hline & Total Normo & 52 & 90 & 142 \\
\hline Weak mutator strains & E. coli & 21 & 20 & 41 \\
\hline & P. mirabilis & - & 7 & 7 \\
\hline $4 \times 10^{-8}<\mathrm{f}<4 \times 10^{-7}$ & K. pneumoniae & 1 & 1 & 2 \\
\hline & C. freundii & - & 4 & 4 \\
\hline & K. oxytoca & - & 1 & 1 \\
\hline & S. marcescens & - & 1 & 1 \\
\hline & C. koseri & - & 1 & 1 \\
\hline & Total Weak & 22 & 35 & 57 \\
\hline Strong mutator strains & E. coli & 2 & 2 & 4 \\
\hline $\mathrm{f}>$ to $4 \times 10^{-7}$ & C. freundii & - & 1 & 1 \\
\hline & Total Strong & 2 & 3 & 5 \\
\hline Total & & 82 & 140 & 222 \\
\hline
\end{tabular}

Table 3A. 


\begin{tabular}{|c|c|c|c|c|}
\hline \multirow{2}{*}{$\begin{array}{l}\text { Mutation } \\
\text { status* }\end{array}$} & \multirow{2}{*}{$\begin{array}{l}\text { Enterobacteriaceae } \\
\text { species }\end{array}$} & \multicolumn{3}{|c|}{ Blood strains } \\
\hline & & $\begin{array}{l}\text { No biofilm } \\
\text { producers** }\end{array}$ & $\begin{array}{l}+ \text { Biofilm } \\
\text { producers }\end{array}$ & Total \\
\hline Hypomutable & E. coli & 5 & 7 & 12 \\
\hline \multirow{7}{*}{$f \leq 8 \times 10^{-9}$} & K. oxytoca & 3 & 4 & 7 \\
\hline & K. pneumoniae & 1 & 1 & 2 \\
\hline & C. koseri & 2 & - & 2 \\
\hline & S. marcescens & 1 & 1 & 2 \\
\hline & M. morganii & - & 1 & 1 \\
\hline & P. mirabilis & 1 & - & 1 \\
\hline & Total Hypo & 13 & 14 & 27 \\
\hline Normomutable strains & E. coli & 59 & 45 & 104 \\
\hline \multirow{11}{*}{$8 \times 10^{-9}<\mathrm{f}<4 \times 10^{-8}$} & K. pneumoniae & 5 & 2 & 7 \\
\hline & P. mirabilis & 7 & - & 7 \\
\hline & E. cloacae & 8 & 1 & 9 \\
\hline & K. oxytoca & 2 & 1 & 3 \\
\hline & S. marcescens & 1 & 2 & 3 \\
\hline & M. morganii & - & 1 & 1 \\
\hline & C. koseri & 1 & 1 & 2 \\
\hline & H. alvei & 1 & 1 & 2 \\
\hline & E. aerogenes & 1 & - & 1 \\
\hline & S. enterica Typhi & - & 1 & 1 \\
\hline & Total Normo & 85 & 55 & 140 \\
\hline \multirow[t]{2}{*}{ Weak mutator strains } & E. coli & 13 & 19 & 32 \\
\hline & K. pneumoniae & 4 & - & 4 \\
\hline \multirow{6}{*}{$4 \times 10^{-8}<\mathrm{f}<4 \times 10^{-7}$} & E. cloacae & 3 & - & 3 \\
\hline & K. oxytoca & - & 1 & 1 \\
\hline & S. marcescens & - & 1 & 1 \\
\hline & E. aerogenes & 1 & - & 1 \\
\hline & M. morganii & 1 & - & 1 \\
\hline & Total Weak & 22 & 21 & 43 \\
\hline Strong mutator strains & E. coli & 1 & - & 1 \\
\hline \multirow{2}{*}{$\mathrm{f} \geq$ to $4 \times 10^{-7}$} & E. cloacae & 2 & - & 2 \\
\hline & Total Strong & 3 & - & 3 \\
\hline Total & & 123 & 90 & 213 \\
\hline
\end{tabular}

Table 3B.

Table 3A-B. Mutation frequencies and ability to form a biofilm (on polystyrene plate) of a collection of clinical Enterobacteriaceae species $(\mathrm{n}=435)$, isolated from blood and urine samples. * Categorisation according to Baquero's criteria (2004). ** Biofilm production was 
calculated as the ODm/ODc ratio as recommended by Stepanovic et al.(2007). The studied strains were classified into 2 categories: no biofilm producers (ratio $\leq 1$ ), +biofilm producers ratio $>1$ ). The raw value of the ratio was used for the correlation calculations.

Higher percentage of urine sample isolates presented in every level of biofilm production. The largest difference between urine and blood strains experienced among the strongest biofilm producers (Figure 4).

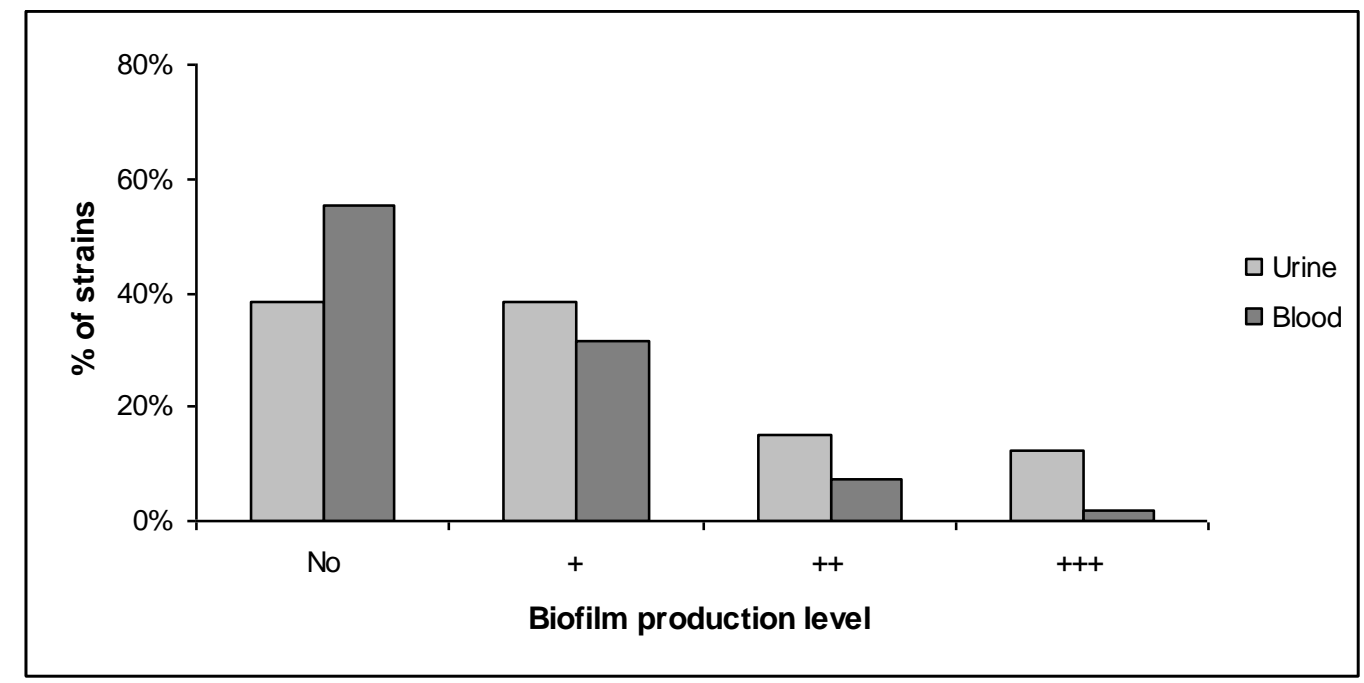

Figure 4. Biofilm production level of Enterobacteriaceae strains: Comparison between strains isolated from urinary tract infections $(\mathrm{n}=222)$ and from bloodstream infections $(\mathrm{n}=213)$. Biofilm production was classified using a 4-group classification system [37].

There was no significant correlation (Pearson's R correlation coefficient and P-values $<0.05$ were considered statistically significant) between mutation frequency and the capacity to initiate a biofilm $(R=0.030$, Figure 5.), irrespective of the source of the strain (urine: $R=0.022$; blood: $\mathrm{R}=0.057$ ) or the group of species $(E$. coli: $\mathrm{R}=0.038$; other Enterobacteriaceae: $\mathrm{R}=0.020$ ). 

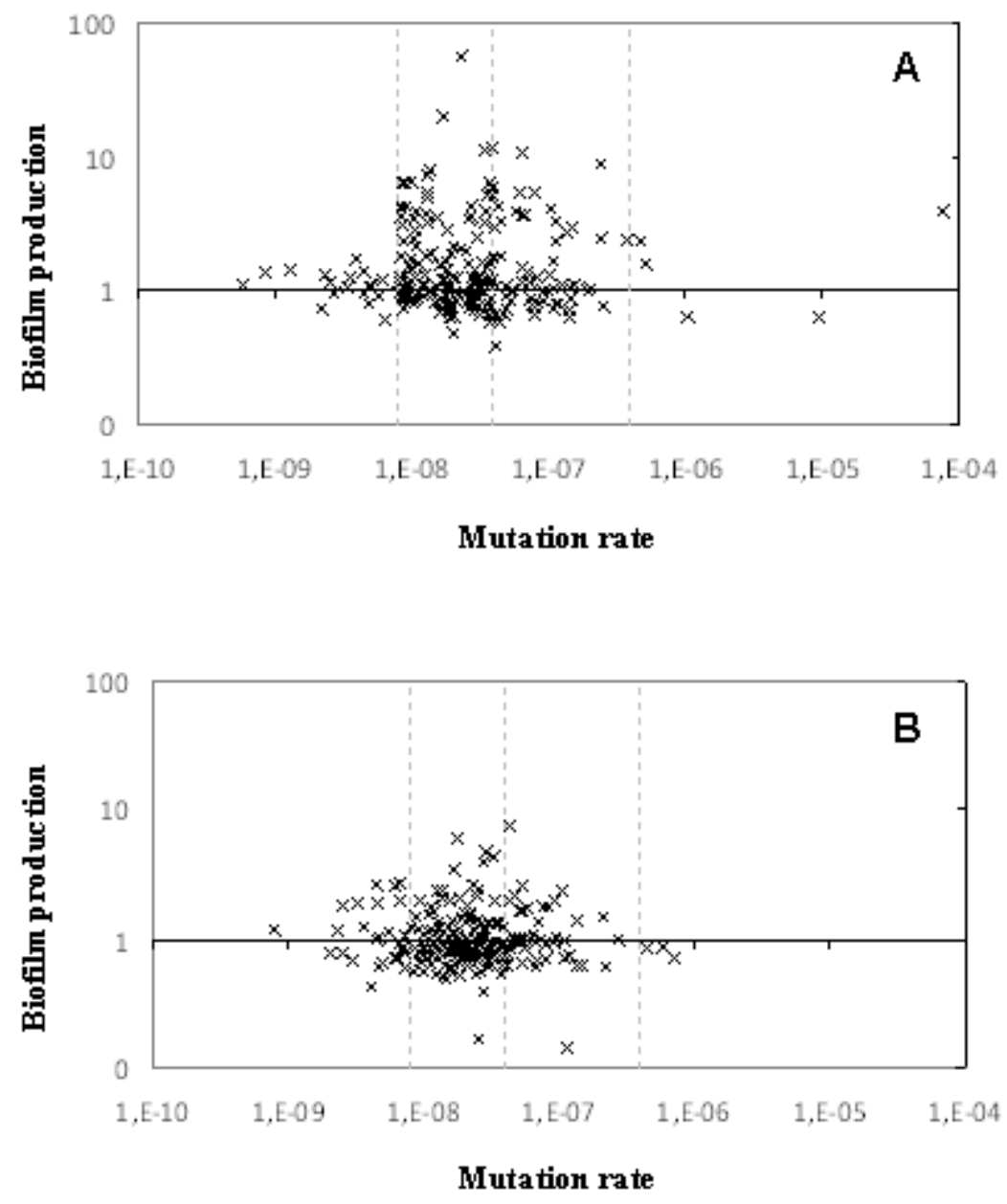

Figure 5. Relationship between rifampicin resistance mutation rates and biofilm production for 435 Enterobacteriaceae strains: 222 from urinary tract infections (A) and 213 from bloodstream infections (B). Biofilm production was calculated as the ODm/ODc ratio as recommended by Stepanovic et al. (2007). The dotted vertical lines indicate the thresholds of mutation according to Baquero et al. (2004).

The ability of the bacterial population to form a biofilm was then studied between the two main peaks of mutation frequencies: $1 \times 10^{-8}\left(1 \times 10-8 \leq \mathrm{f}<2 \times 10^{-8}\right)$ and 10 -fold higher $\left(1 \times 10^{-7} \leq \mathrm{f}<\right.$ $\left.1 \times 10^{-8}\right)$. In the first group, the biofilm production, assessed by the DOm/DOC ratio, ranged from 0.49 to 20.04, with an average of 1.64 and a standard deviation of 2.16. In the second 
group, these values were $0.14,4.13,1.38$ and 0.97 , respectively. The number of strong mutators (i.e. MMR deficient type) was very low and the genetic basis was not characterized.

The highly biofilm-producing strains were normomutators except one weak mutator (E. coli), and 6 out of 7 had a urinary origin (three K. pneumoniae, two E. coli, one K. oxytoca and one $S$. marcescens). Most of the P. mirabilis (7 out of 10) had a weak mutator phenotype, and all of them were biofilm producers (one was +biofilm producer, five were ++biofilm producers, and two were +++ biofilm producers).

\subsection{Susceptibility testing}

Referring to a previous study in the same hospital, from May 2003 through April 2004, activity of fosfomycin on E. coli appears unchanged, in hospitalized patients, in contrast to the increased resistance rates to other antibiotics usually prescribed for UTI [38]. Resistance rate increased by $21 \%$ for amoxicillin, 9\% for amoxicillin combined with clavulanic acid, 3.8\% for third generation cephalosporins, $15.5 \%$ for cotrimoxazole, $8,7 \%$ for first-generation quinolones, and $13.6 \%$ for norfloxacin, and 9,1\% for ciprofloxacin (Table 4.). These results are in line with other recent works [39, 40]. Seven strains harbored an extended-spectrum beta-lactamase (ESBL) phenotype and 11 strains an overproduced cephalosporinase.

\begin{tabular}{|c|c|c|c|c|c|c|c|c|c|c|c|c|}
\hline & Year & Cip & Nor & Nal & Caz & Ctx & Cxt & AC & Amx & Gen & Fos & Tsu \\
\hline $\begin{array}{c}\text { Overall } \\
\text { Resistance }\end{array}$ & 2007 & 18.0 & 22.5 & 23.0 & 8.1 & 8.1 & 11.3 & 56.3 & 68.9 & 5.4 & 6.3 & 34.7 \\
\hline$\%$ & 2004 & 8.9 & 14.3 & & & & 47.3 & 47.9 & & 6.0 & 19.2 \\
\hline
\end{tabular}

Table 4. Comparison of antibiotic resistance in three years' time from the same geographical area. Amx: amoxicillin; AC: amoxicillin clavulanate; Ctn: cephalotin; Cxt: cefoxitin; Ctx: cefotaxime; Caz: ceftazidime; Gen: gentamicin; Fos: fosfomycin; Tsu: cotrimoxazole; Nal: nalidixic acid; Nor: norfloxacin; Cip: ciprofloxacin 
Fluoroquinolon-cotrimoxazole cross resistance in case of ciprofloxacin, norfloxacin and nalidixic acid was $60 \%, 67,5 \%$ and $68 \%$, respectively.

\subsection{Hypermutation and antibiotic resistance}

No significant difference in the distribution of mutator (strong and weak) and non-mutator (normo and hypo) phenotypes was observed between the antibiotic resistant and susceptible isolates for any of the tested antibiotics (Table 5A-B.), neither if we examined the samples as a whole, nor as species by species. The number of strong mutators was too low to demonstrate a possible relationship between antibiotic resistance and acquisition of a strong hypermutator phenotype, although strong mutators were more frequently found in resistant strains, particularly: i) for quinolones, ii) a little for cefotaxime-ceftazidime, and iii) importantly for gentamicin. The percentage of mutators is almost the same among resistant and susceptible groups, except for fosfomycin, where we found just a few isolates (Figure 6.).

\begin{tabular}{|c|c|c|c|c|c|c|c|c|c|c|c|c|}
\hline \multirow{3}{*}{$\begin{array}{c}\text { Mutation } \\
\text { rate } \\
\text { status } \\
\end{array}$} & \multicolumn{12}{|c|}{ Antimicrobial susceptibility } \\
\hline & \multicolumn{2}{|c|}{ Gen } & \multicolumn{2}{|c|}{ Fos } & \multicolumn{2}{|c|}{ Tsu } & \multicolumn{2}{|c|}{ Nal } & \multicolumn{2}{|c|}{ Nor } & \multicolumn{2}{|c|}{ Cip } \\
\hline & $\mathbf{S}$ & $\mathbf{R}$ & $\mathbf{S}$ & $\mathbf{R}$ & $\mathbf{S}$ & $\mathbf{R}$ & $\mathbf{S}$ & $\mathbf{R}$ & $\mathbf{S}$ & $\mathbf{R}$ & $\mathbf{S}$ & $\mathbf{R}$ \\
\hline $\begin{array}{c}\mathbf{H}+\mathbf{N} \\
(\mathbf{n})\end{array}$ & 158 & 8 & 154 & 13 & 108 & 58 & 128 & 38 & 129 & 37 & 136 & 30 \\
\hline $\begin{array}{c}\mathrm{H}+\mathrm{N} \\
(\%)\end{array}$ & 95 & 5 & 92 & 8 & 65 & 35 & 77 & 23 & 78 & 22 & 83 & 17 \\
\hline $\begin{array}{c}\mathbf{W}+\mathbf{S t} \\
(\mathrm{n})\end{array}$ & 52 & 4 & 54 & 1 & 37 & 19 & 43 & 13 & 43 & 13 & 46 & 10 \\
\hline $\begin{array}{c}\mathrm{W}+\mathrm{St} \\
(\%)\end{array}$ & 92 & 8 & 98 & 2 & 66 & 34 & 77 & 23 & 77 & 23 & 82 & 18 \\
\hline$P$ & & & & & & & & & & & & \\
\hline
\end{tabular}

Table 5A. 


\begin{tabular}{cccccccccccccc}
\hline $\begin{array}{c}\text { Mutation } \\
\text { rate } \\
\text { status }\end{array}$ & & \multicolumn{1}{c}{ Antimicrobial susceptibility } \\
\hline & \multicolumn{1}{c}{ Amx } & \multicolumn{1}{c}{ AC } & \multicolumn{1}{c}{ Ctn } & Cxt & Ctx & \multicolumn{2}{c}{ Caz } \\
\hline & S & R & S & R & S & R & S & R & S & R & S & R \\
\hline $\begin{array}{c}\text { H+N } \\
(n)\end{array}$ & 47 & 120 & 70 & 96 & 63 & 103 & 147 & 18 & 153 & 12 & 153 & 12 \\
\hline $\begin{array}{c}\text { H+N } \\
(\%)\end{array}$ & 28 & 72 & 42 & 58 & 38 & 62 & 89 & 11 & 93 & 7 & 93 & 7 \\
\hline $\begin{array}{c}\text { W+St } \\
(n)\end{array}$ & 22 & 33 & 27 & 29 & 27 & 29 & 48 & 7 & 51 & 6 & 51 & 6 \\
\hline $\begin{array}{c}\text { W+St } \\
(\%)\end{array}$ & 40 & 60 & 48 & 52 & 47 & 53 & 88 & 12 & 90 & 10 & 90 & 10 \\
$P$ & 0.08 & 0.36 & 0.237 & 0.88 & 0.512 & 0.415 \\
\hline
\end{tabular}

Table 5B.

Table 5A-B. Statistical analysis comparing the mutation rate status with antimicrobial susceptibility. Mutation frequencies (f) were defined according to Baquero et al (2004): hypomutable H ( $\leq 8 \times 10-9)$, normomutable N $(8 \times 10-9<\mathrm{f}<4 \times 10-8)$, weak mutator W $(4 \times 10-8$ $\leq \mathrm{f}<4 \times 10-7$ ), and strong mutator $\mathrm{S}$ ( $\mathrm{f} \geq$ to $4 \times 10-7)$. Amx: amoxicillin; AC: amoxicillin clavulanate; Ctn: cephalotin; Cxt: cefoxitin; Ctx: cefotaxime; Caz: ceftazidime; Gen: gentamicin; Fos: fosfomycin; Tsu: cotrimoxazole; Nal: nalidixic acid; Nor: norfloxacin; Cip: ciprofloxacin; S susceptible, R: resistant or intermediate; H: hypomutable strains; N: normomutable strains; W: weak mutators; St: strong mutators; $\mathrm{n}$ : number of strains; $\mathrm{p}: p$ value. 


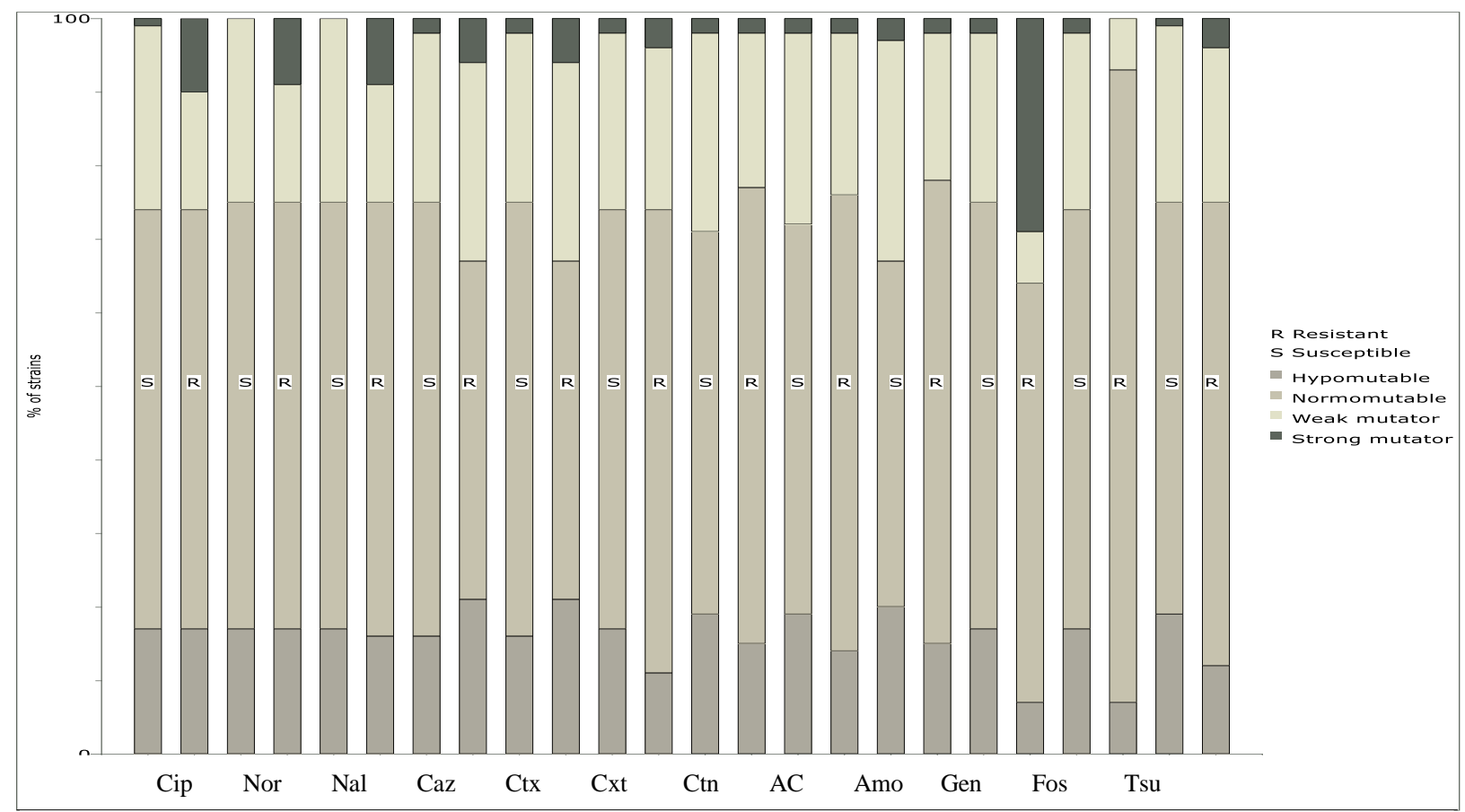

Figure 6. Distribution of mutation frequencies within the susceptible and resistant UTI strains by antibiotics. Amx: amoxicillin; AC: amoxicillin clavulanate; Ctn: cephalotin; Cxt: cefoxitin; Ctx: cefotaxime; Caz: ceftazidime; Gen: gentamicin; Fos: fosfomycin; Tsu: cotrimoxazole; Nal: nalidixic acid; Nor: norfloxacin; Cip: ciprofloxacin.

\section{6 'Highlights' of the clone dendogram}

There were patients with multiple isolates up to 12 , but they had three PFGE patterns at most. Clones with similar PFGE pattern were excluded from the analysis, although interesting information could be gained about the possible changes of the clones during a longer period of time. Comparison of mutation frequency changes and biofilm forming capacity, or possible alteration in the antimicrobial susceptibility could also yield some exciting data. Hence, we examined patients with multiple isolates even though they had similar PFGE pattern.

One third of the patients had the same PFGE pattern with the same antibiogram through their whole series of isolates. One patient's strong mutator clone changed to hypomutable after one and a half month, with a $100 \%$ similarity of its PFGE pattern. Another clone changed to weak 
mutator from strong mutator in three months' time. The third sample got hypomutable from strong mutator in one month, than consequently showed hypomutatbility along with the same antibiogram for six months. One isolate became hypomutable from strong mutator after seven months, with a 97\% PFGE similarity. Our last example showed five isolates with the same PFGE pattern during four months, started with weak mutator phenotype which turned to hypomutable, than normomutable followed by a weak mutator phenotype, which altered to hypomutable in the end.

\section{Discussion}

\subsection{Mutation frequencies}

The distribution of mutation frequencies for the E. coli strains was in close agreement with the distribution reported by Baquero et al, who found a high rate (25\%) of weak mutator and $0.7 \%$ of strong mutator strains in a collection of $696 \mathrm{E}$. coli isolated from urinary tract infections [25]. Polymorphisms in the rifampin resistance mutation frequency for the whole Enterobacteriaceae collection included the blood stream isolates showed similar pattern as well, even in case of excluded E. coli species. These results confirm that the mutation frequency classification developed for E. coli by Baquero and applied to Stenotrophomonas [41] can also be extended to other Enterobacteriaceae species.

Compared to the study by Denamur et al, we found fewer 10 -fold and 50-fold mutator E. coli strains. Using their classification criteria for the whole collection, $4.1 \%$ of the urinary isolates and $1.9 \%$ of blood isolates were 10 -fold mutators, while $0.9 \%$ urinary isolates were 50 -fold mutators and we did not find any from blood cultures. The median value of mutagenesis in the Denamur report was $5 \times 10^{-9}$, meanwhile $2.2 \times 10^{-8}$ in this study, indicating the difficulty to compare different studies and contributing to the controversy in this topic [5]. The difference in the mutagenesis value might be due to geographical variation or differences in host or strain 
characteristics. In 2004 Baquero showed considerable difference in distribution of weak mutators between the Danish (16\%) and Spanish (25\%) E. coli isolates from UTI. In the same study Spanish weak mutators tended to have higher frequencies of mutation than the Swedish ones [25]. In our experiment, there were numerous isolates with an intermediate mutation frequency between the normomutable and weak mutator frequency as well. Since incorrect assessment of the nature of these mutator strains could distort the measurement of the association with the ability to produce a biofilm, we performed a repeated analysis limited to strains with the characteristic rate of $1 \times 10^{-8}$ and $1 \times 10^{-7}$, respectively, considered as normomutators and weak mutators. We found 115 normomutable strains and 27 weak mutators.

\subsection{Hypermutation and biofilm formation}

In the clinical context, it is estimated that $80 \%$ of acute and chronic infections are biofilm-related [42]. Uropathogenic E. coli (UPEC) is known to form biofilms easily [43, 44]. Previous studies are in accordance with our results, showing that biofilm was produced by about half of the strains [45, 46]. However, taking into consideration the site of isolation, this percentage only reached $42.3 \%$ in BSI strains compared with $63.1 \%$ in UTI strains in our series. Soto et al found $43 \%$ and $40 \%$ of biofilm-forming strains from patients with cystitis and pyelonephritis, respectively, while this percentage reached $63 \%$ in case of prostatitis [45].

By definition, hypermutable strains are expected to have higher capacities for adaptation, and some mutations might be linked to an increase in biofilm formation [47]. Numerous studies, especially with $P$. aeruginosa isolated from respiratory samples in patients with cystic fibrosis, showed a higher proportion of hypermutable strains in biofilms. Driffield et al found a 105-fold increase in mutability of P. aeruginosa strains (from CF patients) in biofilm, compared with planktonic cells [48]. Several authors have attempted to explain the large amount of hypermutators in a bacterial population known to readily form biofilms. Bacterial biofilm formation can be induced by DNA damaging agents (involved in mutations) triggering the SOS response, through a connection between stress-inducible biofilm formation and the RecA-LexA interplay [49]. Damaging agents have been described, including silver nanoparticles used for 
their antibacterial properties [50], oxidative product created by other bacteria present in the biofilm (i.e. S. gordonii producing $\mathrm{H} 2 \mathrm{O} 2$ ) [51], or some antibiotics such as fluoroquinolones [52].

To explain the large amount of hypermutators in biofilms, some authors have involved the formation of persister cells, in a quiescent state, rest in the biofilm or inside urothelial cells in the bladder [53] [54]. The appearance of persister cells in the biofilm promotes survival and may be related to the hypermutator phenotype. Persister cells are especially found in late cultures, and therefore in chronic infections. Considering all the above information, we could expect a relationship between the mutation frequency of a collection of clinical Enterobacteriaceae strains and their capacity to initiate a biofilm.

Contrary to what could be expected, there was no significant correlation (Pearson's R correlation coefficient and P-values $<0.05$ were considered statistically significant) between mutation frequency and the capacity to initiate a biofilm $(R=0.030$, Fig. 3$)$, irrespective of the source of the strain (urine: $\mathrm{R}=0.022$; blood: $\mathrm{R}=0.057$ ) or the group of species (E. coli: $\mathrm{R}=0.038$; other Enterobacteriaceae: $\mathrm{R}=0.020)$.

However, association was realized in a small series. As expected with the urease producer Proteus mirabilis, previously described as the predominant organism in biofilms from encrusted catheters [55] and urinary stones, 10/10 (100\%) and 0/8 were biofilm producers in UTIs and BSIs, respectively $(\mathrm{P}<0.001)$. Nevertheless, 7 out of 10 isolates of $P$. mirabilis from UTIs showed a weak mutator phenotype, all of which were biofilm producers in a different level (one was + biofilm producer, five were ++ biofilm producers, and two were +++ biofilm producers).

Thus, solid conclusions may be obtained for weak mutators, but not for MMR deficient strong mutators $(\mathrm{n}=8)$. Moreover, among the few highly biofilm-producing strains, only one weak mutator type (E. coli) was detected, while seven were normomutators among other strains (three $K$. pneumoniae, two E. coli, one $K$. oxytoca and one $S$. marcescens). These strains were mostly isolated from urine samples (6 out of 7).

The relationship between mutation frequency and the capacity to form a biofilm is very complex and could be dependent on the state of growth. Contrary to the mentioned examples, GarcíaCastillo et al showed decreased mutation frequencies of hypermutators in biofilms compared 
with planktonic conditions [56]. The emergence of biofilm production frequently implies increased adhesion between bacterial cells, which could be responsible for errors in estimating the number of colonies counted to measure the frequency of mutation.

\subsection{Hypermutation and antibiotic resistance}

The relationship between the acquisition of antibiotic resistance and hypermutator phenotype is controversial. Mutation frequencies can vary among studies and often did not correlate well with antibiotic-resistant strains known to have developed mutational resistance [57]. In a large series of $S$. aureus, including many methicillin-resistant S. aureus (MRSA) strains, O'Neil and Chopra could not discover a mutator phenotype and concluded that mutator status is not necessary for the generation of high-level vancomycin resistance in S. aureus [58]. Analyzing more than 300 E. coli isolates, Baquero et al were unable to find any significant association between mutator phenotype and resistance against ciprofloxacin in countries with either low or high prevalence of fluoroquinolone resistance [25]. Despite the fact that mutational-antibiotic resistance development was a frequent outcome in a series of 103 acutely infected intensive care unit patients, the prevalence of hypermutable strains was found to be lower than $1 \%$, saying there was no association between hypermutation and resistance [59].

However, significant difference between mutator and non-mutator isolates regarding the antibiotic resistance in cystic fibrosis (CF) lung infection has been previously documented [34, 60]. The same association was found within Staphylococcus aureus isolates in CF patients, although the authors hypothesize easier adaptation benefit prior to the hypermutable feature, because they found several mutations involved in stress response and adaptation [61]. Studying other chronic processes of the lung it was found not only that hypermutable strains were much more resistant to all the antibiotics, but also that most of the antibiotic-resistant strains were hypermutable [32]. Another series showed a more quickly evolved resistance level along with a higher resistance rate in the mutator background than in the wild type (Schaaff et al. 2002) [62]. Hypermutable strains were more frequently found (43\%) in a collection of 89 extended-spectrum beta-lactamase (ESBL)-producing isolates from different patients than in non-ESBL (26\%) $E$. 
coli strains, although these results did not supported either the possibility that mutator strains could be better recipients of ESBL-encoding plasmids or a putative mutagenic effect on the recipient cell derived from the ESBL plasmid acquisition [23]. Komp Lindgren et al have already suggested an unequivocal coherence between elevated mutation rate and fluoroquinolone resistance, by DNA sequencing for fluoroquinolone resistance-associated mutations in E. coli genes [63].

In this study, no significant difference in distribution of mutation frequencies (hypo- and normomutable strains versus weak and strong mutators) was observed between the resistant and susceptible isolates for any of the examined antibiotics, even if the strain was ESBL or AmpC overproducer, or had fluoroquinolone resistance.

However, when statistical analysis compared strong mutators versus all the other strains, a statistical difference was observed only with fluoroquinolones. This data correspond to the fact that point mutation in gyrA gene can result quinolone resistance. Strong mutators were also found in resistant strains a little more frequently for cefotaxime-ceftazidime. Mutation in AmpR transcription regulator may induce the AmpC $\beta$-lactamase [64, 65], which resulted in clones with similar features than ESBL clones, except the fact that they are resistant against $\beta$-lactamases. The association of strong mutators and gentamicin resistance is suggested in figure 6. The number of resistant species was only 12 , out of which $30 \%$ were mutators. The very low resistance rate is welcomed considering the human population, but not enough to draw a solid conclusion. Another interesting data was that pathogens kept showing low resistance rate against fosfomycin, and we found only one mutator amongst them.

\section{4 'Highlights' of the clone dendogram}

PFGE allowed to compare the isolates, which let us define the similarity of the bacteria isolated from different patients or from the same host. Multiple urinary tract infections affecting a patient within a year could be caused by reinfection or relapse. The latter case presumes the continuous presence of the pathogen. Chronicity is an issue in the mutagenesis and transient mutator status, which is thought to be involved in the adaptation of bacteria to the environment. Thus we 
examined all the species belonging to a patient and all the species with the same PFGE pattern. Comparison of mutation frequency changes and biofilm forming capacity, or possible alteration in the antimicrobial susceptibility was determined.

Our results showed examples for mutation frequency changes along with constant PFGE pattern. Variation of shifting included all the possibilities, involving the phenomenon of transient mutator status, which may involve reversion or recombination within the mutator alleles or depletion of the MMR system proteins, allows the organism to temporarily benefit from the elevated mutation frequency for adaptation while reducing the risk of accumulating deleterious mutations. Antibiograms might alter together with changes of the PFGE pattern or mutation frequency as well, although we could not define any association.

\subsection{Critical remarks, limitation of this study}

A significant number of patients had recurrent infection, which presumes former antibiotic consumption. Previous antibiotic treatment possibly contributes to selection of mutators in in vitro experiments. Mutators can be favored under such conditions because they generate antibiotic resistance conferring mutations at a higher rate than what is generated by nonmutators. In addition, they also generate more mutations that compensate for the fitness reduction associated with antibiotic resistance [5]. We could not control the prescriptions made by other hospitals or the general practitioners and did not have information about the antibiotic consumption and about the course of healing, which rises several unanswerable questions like what kind of antibiotics did they receive and how long, were these infections due to resistant strains, whether the selected patients got the sufficiently prolonged therapy for that certain infection, was there a therapy failure, is there impairment between therapy failure and the development of resistance. Consequently, the effect of previous antibiotic treatment on our results is inestimable. 


\section{Conclusions}

We were the first to confirm that the mutation frequency classification developed for E. coli by Baquero et al and applied to Stenotrophomonas [41] can also be extended to other Enterobacteriaceae species isolated from urinary tract infections.

We could not show linear dependence or significant correlation between mutation frequency and the capacity to initiate a biofilm. However, association was realized in a small series of Proteus mirabilis, where 7 out of 10 isolates were weak mutators, all of which were biofilm producers. This association may support our basic idea of this research, as cystic fibrosis and certain urinary tract infections are similar in a certain respect. Further investigation with larger $P$. mirabilis sample size might refine this relationship. Not finding a correlation between increased mutation frequency and initiation of biofilms in Enterobacteriaceae might be directly linked to the fact that strains were mainly isolated from acute infections, and does not mean that there is no relevant effect of mutation frequency in other stages or aspects of biofilm growth.

We found statistical difference between the antibiotic resistant and susceptible isolates for the tested antibiotics in case of quinolones, when the analysis compared strong mutators versus all the other strains, but we found no significant difference in the distribution of mutator (strong and weak) and non-mutator (normo- and hypo-) phenotypes. Although the number of strong mutators was too low to demonstrate a possible relationship between antibiotic resistance and acquisition of a strong mutator phenotype. The same conclusion has to be drawn for gentamicin, although the suggested association is an unexpected finding and would be a promising novelty, the sample size is sparse.

Alteration in mutation frequency and antibiotic resistance in isolates with identical PFGE patterns belonging to the same patients suggests the importance of chronicity and transient

mutator status. Further investigation of these features might help to better understand the mechanisms of bacterial adaptation. 


\section{Acknowledgements}

This work was supported by the European Urological Scholarship Program (EUSP) of the European Association of Urology (EAU) and by grants from Conseil Regional de Bretagne and from Fondation des Gueules Cassees.

I thank Marie-France Travert for technical assistance with PFGE and Anne-Marie Gouraud for technical assistance with the biofilm assays.

I express my gratitude to my mentor, Anne Jolivet-Gougeon, who introduced me to the world of clinical microbiology examinations, showed me the associations of the topic and taught me the know-how of writing the articles. Her persistent hard work gave me the model and her continuous care encouraged me to step over the difficulties during my scholarship year.

I give special thanks to my chief, Peter Tenke, who taught me to combine clinical and scientific work, showed me the road to science and provided all the circumstances to pursue this work.

I thank my colleagues in the department for undertake more work during my absence from the hospital.

Finally I thank the most to my wife and daughters to support me and to show great tolerance for my absence from family life. 


\section{Magyar nyelvü összefoglaló}

\section{Hipermutáció szerepe a biofilm képződésben és az antibiotikum rezisztencia kialakulásában Enterobacteriaceae családba tartozó kórokozók által okozott húgyúti fertőzésekben}

\subsection{Bevezetés}

A fertőző betegségek gyógyítását a mikroorganizmusok újabbnál újabb túlélési mechanizmusokkal nehezítik meg. Kutatások támasztják alá, hogy a mutációnak, amely a baktériumok természetesen meglevő tulajdonsága, alapvető szerepe van a kórokozók adaptációjában, és szelekciós előnyt jelent [2,3]. Mutáns laboratóriumi sejtvonalakban korai tanulmányok olyan mutátorokat figyeltek meg, melyek különböző szelekciós stratégiákkal rendelkeztek. LeClerc és munkatársai E. coli és Salmonella egyedeket vizsgálva magas mutációs frekvenciáról számoltak be, amely megkérdőjelezte azon elmélet létjogosultságát, mely szerint baktérium populációkban a mutátorok elöfordulása ritka. Ezen eredmények azt mutatták, hogy természetes populációk a környezeti szelekciós nyomásra két módon reagáltak, megemelt mutációs frekvenciával, és rekombinációval.

Adott populációban, adott időben a mutációk száma meghatározható, mely megadja a populáció mutációs frekvenciáját (f). Ismertek olyan organizmusok, klinikai pathogéneket is beleértve, amelyek 10-1000 szeres, vagy akár még nagyobb állandó mutációs frekvenciával rendelkeznek saját populációjuk medián értékéhez képest, melyet hipermutációnak nevezünk. Kutatásom elött az irodalomban E. coli-tól eltekintve nem volt adat húgyúti infekciókból származó más, Enterobacteriaceae családba tartózó kórokozók hipermutátor prevalenciájáról.

A hipermutáció és biofilm formáló készség, illetve hipermutáció és antibiotikum rezisztencia közötti kapcsolat vizsgálatának ötlete a következőkben részletezett megfigyeléseken alapult. Az antibiotikum rezisztencia emelkedése az egész emberiséget érintő probléma, mely a húgyúti infekciókban (HI) használatos szinte összes antibiotikumot érinti. Kísérletesen igazolt, hogy a 
húgyúti infekciókban magasabb a hipermutátorok aránya, mint más lokalizációjú fertőzésekben [5, 25], mellesleg a vizsgálatok arra is rámutatottak, hogy a mutációs frekvenciában földrajzi különbségek is megfigyelhetők. Továbbá, mind a biofilm képződésnek, mind az antibiotikum rezisztencia kialakulásának széles irodalma van a HI-k terén. Létezik egy klinikai entitás, melyben a fent említett hipermutáció és biofilm képződés, illetve hipermutáció és antibiotikum rezisztencia között szignifikáns összefüggést mutattak ki. A betegség nem más, mint a cisztás fibrózis tüdő érintettsége. Mucoviscidosisban az alveolusok, brochiolusok a betegség kapcsán keletkező sürü szekrétum miatt elzáródnak, melyben baktérium kolóniák, és ezzel összefüggésben fertőzések alakulnak ki. Hosszú távon az említett nyákban biofilm képződik, mely biztonságos mikrokörnyezetet biztosít a benne élő kórokozóknak, megnehezíti az antibiotikumok penetrációját, és a fertőzés gyógyítását.

Krónikus fertőzés, bakteriális adaptáció, un. perziszter klónok, tranziens mutátorok jelenléte, védelem az antibiotikumokkal szemben, antibiotikum, mint szelekciós tényező. Ezek azok a jelenségek, amelyek cisztás fibrózisban és húgyúti fertőzések egy részében is jelen vannak, és ezért bizonyos tekintetben hasonlóvá teszik a két betegséget. Ez adta az ötletet, hogy megvizsgáljuk a hipermutáció és biofilm képződés, illetve antibiotikum rezisztencia kapcsolatát húgyúti fertőzésekben.

Hipotézisünk szerint az Enterobacteriaceae családba, mint a leggyakoribb urológiai kórokozók közé tartozó egyedek hipermutátor fenotípusai nagyobb valószínüséggel lesznek antibiotikumokra rezisztensek. Továbbá, minél magasabb a patogén mutációs frekvenciája, annál gyakrabban szerez biofilm képző képességet. Céljaink között szerepelt (1) a mutációs frekvencia meghatározásának kiterjesztése Enterobacteriaceae családba tartozó, húgyúti fertőzések során vizeletből és hemokultúrából kitenyészett kórokozókra. (2) Az izolátumok biofilm inicializáló kapacitásának vizsgálata. (3) A mutációs frekvencia és biofilm képző képesség között lehetséges kapcsolat feltárása. (4) A kórokozók HI-ban leggyakrabban használt antibiotikumokkal szembeni rezisztenciájának meghatározása. (5) A hipermutátorok és fokozott antibiotikum rezisztencia között lehetséges kapcsolat feltárása. 


\subsection{Beteganyag és módszer}

A vizsgálat első fázisában egy bretagne-i egyetemi klinikán (Equipe Microbiologie, Université de Rennes 1, France) a 2007-es évben beérkezett négyezer klinikai mintából Enterobacteriaceae családba tartozó vizelet mintákat szelektáltunk. Az izolátumok tisztaságát ellenőriztük, a polimikróbás anyagokat a vizsgálatból kizártuk, majd speciális, többszöri mintavételre alkalmas hordozóban, mélyfagyasztva tároltuk a kórokozókat. A klónokat gél elektroforézis után dendogram analízisnek vetettük alá annak érdekében, hogy csak egyedi izolátumok kerüljenek a vizsgálatba.

A kórokozók antibiotikumokkal szembeni érzékenységet diszk diffúziós teszt illetve $\mathrm{E}$ teszt segítségével határozták meg a klinikai megjelenés kapcsán, melyekből a HI-ban leggyakrabban használt hatóanyagokat vettük figyelembe. Az AmpC típusú $\beta$-laktamáz termelő és ESBL (extended spectrum $\beta$-laktamase) termelő izolátumokat is meghatároztuk.

A mutációs frekvencia becsléséhez az egyes törzsekben a mutáció következtében létrejött rifampicin rezisztencia mértékét használtuk fel, rifampicin dilúciós teszt segítségével. A mutációs frekvenciák osztályozását kétféleképpen végeztük el, egyrészt Baquero definíciója szerint négy kategóriát határozva meg, úgymint hipomutábilis (f $\left.\leq 8 \times 10^{-9}\right)$, normomutábilis $\left(8 \times 10^{-9}<\mathrm{f}<4 \times 10^{-8}\right)$, a hipermutátorokat két csoportba sorolva: gyenge mutátor $\left(4 \times 10^{-8} \leq \mathrm{f}<\right.$ $4 \times 10^{-7}$ ), és erős mutátor ( $\mathrm{f} \geq \mathrm{t} 4 \times 10^{-7}$ ) fajok [25], illetve Denamur csoportosítását használva. Utóbbi szerint mutátor az az izolátum, melynek rifampicinnel szembeni rezisztenciája kapcsán jelentkező mutációinak száma tízszerese a vizsgált populáció medián mutagenezisének. Ezeket tízszeres mutátoroknak nevezte el, amely klónok > 50x mutációs frekvenciát mutattak, azokat pedig erős mutátoroknak tekintette [5].

A kutatás harmadik lépcsőjében a kórokozók adherencia képességének, mint a biofilm képződés kezdeti lépésének meghatározását végeztük el, Stepanovic módszerét némi módosítással alkalmazva [37].

A statisztikai elemzéshez kétoldalú Fischer's exact tesztet, és a Mantel-Haenszel khi-négyzet tesztet, illetve a Student-féle $t$ és khi-négyzet tesztet alkalmaztunk. 
A hemokultúrából származó egyedeket a klinika alkalmazottai vizsgálták a fent leírt módszereknek megfelelően, végül 213 izolátummal kapcsolatos adatbázist bocsátottak rendelkezésünkre az összehasonlító vizsgálatokhoz.

\subsection{Eredmények}

Háromszázhatvankilenc húgyúti fertőzésből izolált, Enterobacteriaceae családba tartozó kórokozóból a PFGE 222 egyedi klónt határozott meg, melyek eloszlását az 1. táblázat tartalmazza.

A Baquero által meghatározott négy kategóriának megfelelően a törzsek 10.3\%-a volt hipomutábilis, $64.8 \%$ normomutábilis, $23 \%$ gyenge mutátor és $1.8 \%$ erős mutátor. Az Enterobacteriaceae családra, mint egészre vonatkozó eloszlási adatok közeli hasonlóságot mutattak a fent említett beosztáshoz akkor is, ha az E. coli-kat kihagytuk a számításból. A Denamur-féle felosztás szerint a húgyúti mintákból származó E. coli-k esetében a 10x és 50x mutátorok megoszlása $4.1 \%$ és $0.9 \%$, míg hemokultúrákban $1.9 \%$ volt 10x mutátor, és nem találtunk 50x mutátort.

Szignifikáns különbség nem mutatkozott a mutációs frekvencia és biofilm iniciáló képesség között, függetlenül az izolátum forrásától vagy a speciestől. Vizeletből származó mintákban minden biofilm kategóriában nagyobb volt az esetszám a hemokultúrákhoz képest. Összességében a húgyúti minták 63.1\%-a, míg a hemokultúrák 42.3\%-a mutatott biofilm inicializáló tulajdonságot. A vizeletből származó $P$. mirabilis egyedek mindegyike biofilm képző volt, és a tízből hét gyenge mutátor tulajdonsággal is rendelkezett.

A vizsgált antibiotikumokkal szembeni rezisztencia növekedése egy három évvel korábbi felméréshez képest a következő értékeket mutatta: nalidix-sav $8.7 \%$, ciprofloxacin 9.1\%, norfloxacin $13.6 \%$, harmadik generációs cefalosporinok $3.8 \%$, fosfomycin $6.1 \%$, gentamicin $5.7 \%$, amoxicillin $21 \%$, amoxicillin-klavulánsav $9 \%$ és trimethoprim-sulfamethoxazol $15.5 \%$.

A mutátor (erős és gyenge mutátorok csoportja) és non-mutátor (normo- és hipomutábilis kórokozók) fenotípusok között az érzékeny és rezisztens tulajdonság tekintetében egyik vizsgált antibiotikum esetében sem mutatkozott szignifikáns különbség. Ha az erős mutátorok csoportját 
állítottuk szembe a gyenge mutátorok, normo- és hipomutábilis kórokozók csoportjával, akkor a kinolonoknál szignifikáns összefüggés mutatkozott az erős mutátor fenotípus és az antibiotikum rezisztencia jelenléte között $(\mathrm{P}<0,001)$. Azonos betegből származó, azonos PFGE mintázatot mutató kórokozók között változatos mutációs frekvenciájú klónokat mutattunk ki.

\subsection{Megbeszélés}

Vizsgálatunkban a mutációs frekvencia eloszlás megegyezett a Baquero által közölt adatokkal, mi több, az Enterobacteriaceae-k családját tekintve is azonos volt, akkor is, ha az E. coli izolátumokat kihagytuk a számításból. Erre vonatkozó adat korábban nem szerepelt az irodalomban.

Hipermutáció és biofilm képző sajátosság között nem sikerült szignifikáns kapcsolatot kimutatni, de összefüggés mutatkozott egy kis csoport tekintetében. Ahogy az várható volt, minden $P$. mirabilis izolátum biofilm képző volt a húgyúti mintákban, ugyanakkor tízből hét kórokozó gyenge mutátornak bizonyult. Alapfelvetésünket, mely szerint bizonyos tekintetben azonosság mutatkozik a cisztás fibrózis és bizonyos húgyúti infekciók körülményei között, utóbbi összefüggés alátámaszthatja. Nagyobb esetszámú vizsgálat tovább finomíthatná a jelenséget.

Bár a hipermutáció és az antibiotikum rezisztencia kialakulása közötti logikusnak tűnő kapcsolat igazolására számos vizsgálatot végeztek, az eredmények ellentmondásosak. Vizsgálatunkban statisztikai különbség mutatkozott a kinolon rezisztencia, és az erős mutátorok verzusz nem erős mutátorok (ide értve a gyenge mutátorok, normál populáció és hipomutábilis törzsek csoportját) között, azaz kimutathatóan több rezisztens kórokozó volt az erős mutátorok csoportjában, mely összecseng a gyrA génben létrejövő pont mutáció okozta fluorokinolon rezisztencia előfordulásával. Ugyanezen, de nem szignifikáns összefüggést igazoltuk gentamicinnel szemben is, mely nem várt eredmény, és bíztató újdonságnak számítana, de a kis esetszám statisztikai ereje nem elegendő az egyértelmü összefüggés kimondásához.

Azonos PFGE mintázatú, ugyanattól a betegtől származó kórokozók változó mutációs frekvenciája és antibiotikum rezisztenciája felhívja a figyelmet az elhúzódó bakteriális jelenlét és a tranziens mutátor státus jelentőségére, melyek további vizsgálata hozzásegíthet a baktériumok adaptációs mechanizmusainak megértéséhez. 


\section{References}

1. Chou HH, Berthet J, and Marx CJ, Fast growth increases the selective advantage of a mutation arising recurrently during evolution under metal limitation. PLoS Genet, 2009. 5(9): p. e1000652.

2. Cooper TF, Recombination speeds adaptation by reducing competition between beneficial mutations in populations of Escherichia coli. PLoS Biol, 2007. 5(9): p. e225.

3. LeClerc JE, Li B, Payne WL, and Cebula TA, High mutation frequencies among Escherichia coli and Salmonella pathogens. Science, 1996. 274(5290): p. 1208-11.

4. Rosche WA and Foster PL, The role of transient hypermutators in adaptive mutation in Escherichia coli. Proc Natl Acad Sci U S A, 1999. 96(12): p. 6862-7.

5. Denamur E, Bonacorsi S, Giraud A, Duriez P, Hilali F, Amorin C, Bingen E, Andremont A, Picard B, Taddei F, and Matic I, High frequency of mutator strains among human uropathogenic Escherichia coli isolates. J Bacteriol, 2002. 184(2): p. 605-9.

6. $\quad$ Siegel EC and Bryson V, Mutator gene of Escherichia coli B. J Bacteriol, 1967. 94(1): p. 38-47.

7. Oliver A, Baquero F, and Blazquez J, The mismatch repair system (mutS, mutL and uvrD genes) in Pseudomonas aeruginosa: molecular characterization of naturally occurring mutants. Mol Microbiol, 2002. 43(6): p. 1641-50.

8. Chopra I, O'Neill AJ, and Miller K, The role of mutators in the emergence of antibioticresistant bacteria. Drug Resist Updat, 2003. 6(3): p. 137-45.

9. Zeibell K, Aguila S, Yan Shi V, Chan A, Yang H, and Miller JH, Mutagenesis and repair in Bacillus anthracis: the effect of mutators. J Bacteriol, 2007. 189(6): p. 2331-8.

10. Haber LT, Pang PP, Sobell DI, Mankovich JA, and Walker GC, Nucleotide sequence of the Salmonella typhimurium mutS gene required for mismatch repair: homology of MutS and HexA of Streptococcus pneumoniae. J Bacteriol, 1988. 170(1): p. 197-202.

11. Prudhomme M, Mejean V, Martin B, and Claverys JP, Mismatch repair genes of Streptococcus pneumoniae: HexA confers a mutator phenotype in Escherichia coli by negative complementation. J Bacteriol, 1991. 173(22): p. 7196-203.

12. Reenan RA and Kolodner RD, Isolation and characterization of two Saccharomyces cerevisiae genes encoding homologs of the bacterial HexA and MutS mismatch repair proteins. Genetics, 1992. 132(4): p. 963-73.

13. Marinus MG, DNA methylation and mutator genes in Escherichia coli K-12. Mutat Res, 2010. 705(2): p. 71-6.

14. Zaleski $\mathrm{P}$ and Piekarowicz A, Characterization of a dam mutant of Haemophilus influenzae Rd. Microbiology, 2004. 150(Pt 11): p. 3773-81.

15. Chen L, Paulsen DB, Scruggs DW, Banes MM, Reeks BY, and Lawrence ML, Alteration of DNA adenine methylase (Dam) activity in Pasteurella multocida causes increased spontaneous mutation frequency and attenuation in mice. Microbiology, 2003. 149(Pt 8): p. 2283-90.

16. Nouvel LX, Dos Vultos T, Kassa-Kelembho E, Rauzier J, and Gicquel B, A non-sense mutation in the putative anti-mutator gene ada/alkA of Mycobacterium tuberculosis and M. bovis isolates suggests convergent evolution. BMC Microbiol, 2007. 7: p. 39. 
17. Itakura M, Tabata K, Eda S, Mitsui H, Murakami K, Yasuda J, and Minamisawa K, Generation of Bradyrhizobium japonicum mutants with increased $N 2 O$ reductase activity by selection after introduction of a mutated dnaQ gene. Appl Environ Microbiol, 2008. 74(23): p. 7258-64.

18. Rodriguez-Rojas A and Blazquez J, The Pseudomonas aeruginosa pfpI gene plays an antimutator role and provides general stress protection. J Bacteriol, 2009. 191(3): p. 844-50.

19. Harris RS, Longerich S, and Rosenberg SM, Recombination in adaptive mutation. Science, 1994. 264(5156): p. 258-60.

20. Worth L, Jr., Clark S, Radman M, and Modrich P, Mismatch repair proteins MutS and MutL inhibit RecA-catalyzed strand transfer between diverged DNAs. Proc Natl Acad Sci U S A, 1994. 91(8): p. 3238-41.

21. Zahrt TC, Mora GC, and Maloy S, Inactivation of mismatch repair overcomes the barrier to transduction between Salmonella typhimurium and Salmonella typhi. J Bacteriol, 1994. 176(5): p. 1527-9.

22. Martinez JL and Baquero F, Mutation frequencies and antibiotic resistance. Antimicrob Agents Chemother, 2000. 44(7): p. 1771-7.

23. Baquero MR, Galan JC, del Carmen Turrientes M, Canton R, Coque TM, Martinez JL, and Baquero F, Increased mutation frequencies in Escherichia coli isolates harboring extended-spectrum beta-lactamases. Antimicrob Agents Chemother, 2005. 49(11): p. 4754-6.

24. Le Gall S, Desbordes L, Gracieux P, Saffroy S, Bousarghin L, Bonnaure-Mallet M, and Jolivet-Gougeon A, Distribution of mutation frequencies among Salmonella enterica isolates from animal and human sources and genetic characterization of a Salmonella Heidelberg hypermutator. Vet Microbiol, 2009. 137(3-4): p. 306-12.

25. Baquero MR, Nilsson AI, Turrientes Mdel C, Sandvang D, Galan JC, Martinez JL, Frimodt-Moller N, Baquero F, and Andersson DI, Polymorphic mutation frequencies in Escherichia coli: emergence of weak mutators in clinical isolates. J Bacteriol, 2004. 186(16): p. 5538-42.

26. van Loosdrecht MC, Lyklema J, Norde W, Schraa G, and Zehnder AJ, The role of bacterial cell wall hydrophobicity in adhesion. Appl Environ Microbiol, 1987. 53(8): p. 1893-7.

27. van Loosdrecht MC, Lyklema J, Norde W, Schraa G, and Zehnder AJ, Electrophoretic mobility and hydrophobicity as a measured to predict the initial steps of bacterial adhesion. Appl Environ Microbiol, 1987. 53(8): p. 1898-901.

28. Costerton JW, Introduction to biofilm. Int J Antimicrob Agents, 1999. 11(3-4): p. 217-21; discussion 237-9.

29. Denstedt JD, Wollin TA, and Reid G, Biomaterials used in urology: current issues of biocompatibility, infection, and encrustation. J Endourol, 1998. 12(6): p. 493-500.

30. Tenke P, Kovacs B, Jackel M, and Nagy E, The role of biofilm infection in urology. World J Urol, 2006. 24(1): p. 13-20.

31. Conibear TC, Collins SL, and Webb JS, Role of mutation in Pseudomonas aeruginosa biofilm development. PLoS One, 2009. 4(7): p. e6289.

32. Macia MD, Blanquer D, Togores B, Sauleda J, Perez JL, and Oliver A, Hypermutation is a key factor in development of multiple-antimicrobial resistance in Pseudomonas 
aeruginosa strains causing chronic lung infections. Antimicrob Agents Chemother, 2005. 49(8): p. 3382-6.

33. Matic I, Radman M, Taddei F, Picard B, Doit C, Bingen E, Denamur E, and Elion J, Highly variable mutation rates in commensal and pathogenic Escherichia coli. Science, 1997. 277(5333): p. 1833-4.

34. Oliver A, Canton R, Campo P, Baquero F, and Blazquez J, High frequency of hypermutable Pseudomonas aeruginosa in cystic fibrosis lung infection. Science, 2000. 288(5469): p. 1251-4.

35. Picard B, Duriez P, Gouriou S, Matic I, Denamur E, and Taddei F, Mutator natural Escherichia coli isolates have an unusual virulence phenotype. Infect Immun, 2001. 69(1): p. 9-14.

36. Allardet-Servent A, Bouziges N, Carles-Nurit MJ, Bourg G, Gouby A, and Ramuz M, Use of low-frequency-cleavage restriction endonucleases for DNA analysis in epidemiological investigations of nosocomial bacterial infections. J Clin Microbiol, 1989. 27(9): p. 2057-61.

37. Stepanovic S, Vukovic D, Hola V, Di Bonaventura G, Djukic S, Cirkovic I, and Ruzicka F, Quantification of biofilm in microtiter plates: overview of testing conditions and practical recommendations for assessment of biofilm production by staphylococci. APMIS, 2007. 115(8): p. 891-9.

38. Lobel B, Valot A, Cattoir V, Lemenand O, and Gaillot O, [Comparison of antimicrobial susceptibility of 1,217 Escherichia coli isolates from women with hospital and community-acquired urinary tract infections]. Presse Med, 2008. 37(5 Pt 1): p. 746-50.

39. Johnson L, Sabel A, Burman WJ, Everhart RM, Rome M, MacKenzie TD, Rozwadowski $\mathrm{J}$, Mehler PS, and Price CS, Emergence of fluoroquinolone resistance in outpatient urinary Escherichia coli isolates. Am J Med, 2008. 121(10): p. 876-84.

40. Caterino JM, Weed SG, Espinola JA, and Camargo CA, Jr., National trends in emergency department antibiotic prescribing for elders with urinary tract infection, 1996-2005. Acad Emerg Med, 2009. 16(6): p. 500-7.

41. Turrientes MC, Baquero MR, Sanchez MB, Valdezate S, Escudero E, Berg G, Canton R, Baquero F, Galan JC, and Martinez JL, Polymorphic mutation frequencies of clinical and environmental Stenotrophomonas maltophilia populations. Appl Environ Microbiol, 2010. 76(6): p. 1746-58.

42. Hall-Stoodley L, Costerton JW, and Stoodley P, Bacterial biofilms: from the natural environment to infectious diseases. Nat Rev Microbiol, 2004. 2(2): p. 95-108.

43. Choong $\mathrm{S}$ and Whitfield $\mathrm{H}$, Biofilms and their role in infections in urology. BJU Int, 2000. 86(8): p. 935-41.

44. Tenke P, Koves B, Nagy K, Hultgren SJ, Mendling W, Wullt B, Grabe M, Wagenlehner FM, Cek M, Pickard R, Botto H, Naber KG, and Bjerklund Johansen TE, Update on biofilm infections in the urinary tract. World J Urol, 2012. 30(1): p. 51-7.

45. Soto SM, Smithson A, Martinez JA, Horcajada JP, Mensa J, and Vila J, Biofilm formation in uropathogenic Escherichia coli strains: relationship with prostatitis, urovirulence factors and antimicrobial resistance. J Urol, 2007. 177(1): p. 365-8.

46. Rijavec M, Muller-Premru M, Zakotnik B, and Zgur-Bertok D, Virulence factors and biofilm production among Escherichia coli strains causing bacteraemia of urinary tract origin. J Med Microbiol, 2008. 57(Pt 11): p. 1329-34. 
47. Jayaraman R, Hypermutation and stress adaptation in bacteria. J Genet, 2011. 90(2): p. 383-91.

48. Driffield KL, Bostock JM, Miller K, O'Neill A J, Hobbs JK, and Chopra I, Evolution of extended-spectrum beta-lactamases in a MutS-deficient Pseudomonas aeruginosa hypermutator. J Antimicrob Chemother, 2006. 58(4): p. 905-7.

49. Gotoh H, Kasaraneni N, Devineni N, Dallo SF, and Weitao T, SOS involvement in stressinducible biofilm formation. Biofouling, 2010. 26(5): p. 603-11.

50. Radzig MA, Nadtochenko VA, Koksharova OA, Kiwi J, Lipasova VA, and Khmel IA, Antibacterial effects of silver nanoparticles on gram-negative bacteria: influence on the growth and biofilms formation, mechanisms of action. Colloids Surf B Biointerfaces, 2013. 102: p. 300-6.

51. Itzek A, Zheng L, Chen Z, Merritt J, and Kreth J, Hydrogen peroxide-dependent DNA release and transfer of antibiotic resistance genes in Streptococcus gordonii. J Bacteriol, 2011. 193(24): p. 6912-22.

52. Morero NR, Monti MR, and Argarana CE, Effect of ciprofloxacin concentration on the frequency and nature of resistant mutants selected from Pseudomonas aeruginosa mutS and mutT hypermutators. Antimicrob Agents Chemother, 2011. 55(8): p. 3668-76.

53. Blango MG and Mulvey MA, Persistence of uropathogenic Escherichia coli in the face of multiple antibiotics. Antimicrob Agents Chemother, 2010. 54(5): p. 1855-63.

54. Wang $\mathrm{X}$ and Wood TK, Toxin-antitoxin systems influence biofilm and persister cell formation and the general stress response. Appl Environ Microbiol, 2011. 77(16): p. 5577-83.

55. Jacobsen SM and Shirtliff ME, Proteus mirabilis biofilms and catheter-associated urinary tract infections. Virulence, 2011. 2(5): p. 460-5.

56. Garcia-Castillo M, del Campo R, Baquero F, Morosini MI, Turrientes MC, Zamora J, and Canton R, Stationary biofilm growth normalizes mutation frequencies and mutant prevention concentrations in Pseudomonas aeruginosa from cystic fibrosis patients. Clin Microbiol Infect, 2011. 17(5): p. 704-11.

57. Woodford $\mathrm{N}$ and Ellington MJ, The emergence of antibiotic resistance by mutation. Clin Microbiol Infect, 2007. 13(1): p. 5-18.

58. O'Neill AJ and Chopra I, Lack of evidence for involvement of hypermutability in emergence of vancomycin-intermediate Staphylococcus aureus. Antimicrob Agents Chemother, 2003. 47(4): p. 1484-5; author reply 1485.

59. Gutierrez O, Juan C, Perez JL, and Oliver A, Lack of association between hypermutation and antibiotic resistance development in Pseudomonas aeruginosa isolates from intensive care unit patients. Antimicrob Agents Chemother, 2004. 48(9): p. 3573-5.

60. Henrichfreise B, Wiegand I, Pfister W, and Wiedemann B, Resistance mechanisms of multiresistant Pseudomonas aeruginosa strains from Germany and correlation with hypermutation. Antimicrob Agents Chemother, 2007. 51(11): p. 4062-70.

61. Prunier AL, Malbruny B, Laurans M, Brouard J, Duhamel JF, and Leclercq R, High rate of macrolide resistance in Staphylococcus aureus strains from patients with cystic fibrosis reveals high proportions of hypermutable strains. J Infect Dis, 2003. 187(11): p. 1709-16.

62. Schaaff F, Reipert A, and Bierbaum G, An elevated mutation frequency favors development of vancomycin resistance in Staphylococcus aureus. Antimicrob Agents Chemother, 2002. 46(11): p. 3540-8. 
63. Komp Lindgren $\mathrm{P}$, Karlsson A, and Hughes D, Mutation rate and evolution of fluoroquinolone resistance in Escherichia coli isolates from patients with urinary tract infections. Antimicrob Agents Chemother, 2003. 47(10): p. 3222-32.

64. Lindberg F, Westman L, and Normark S, Regulatory components in Citrobacter freundii ampC beta-lactamase induction. Proc Natl Acad Sci U S A, 1985. 82(14): p. 4620-4.

65. Honore N, Nicolas MH, and Cole ST, Inducible cephalosporinase production in clinical isolates of Enterobacter cloacae is controlled by a regulatory gene that has been deleted from Escherichia coli. EMBO J, 1986. 5(13): p. 3709-14. 
I. 

II. 
